\title{
Reduced Disposal Area Performance Utilizing Secondary-Treated Effluent in Profile-Limiting Soils
}

\author{
David A. Meints, Kristofor R. Brye*, Larry T. West, Lisa S. Wood \\ Department of Crop, Soil, and Environmental Sciences, University of Arkansas, Fayetteville, AR, USA \\ Email: david@meincowastewater.com, ^kbrye@uark.edu, larrywestar@gmail.com, lswood@uark.edu
}

How to cite this paper: Meints, D.A., Brye, K.R., West, L.T. and Wood, L.S. (2019) Reduced Disposal Area Performance Utilizing Secondary-Treated Effluent in Profile-Limiting Soils. Journal of Environmental Protection, 10, 745-771.

https://doi.org/10.4236/jep.2019.106045

Received: May 7, 2019

Accepted: June 14, 2019

Published: June 17, 2019

Copyright ( 2019 by author(s) and Scientific Research Publishing Inc. This work is licensed under the Creative Commons Attribution International License (CC BY 4.0). http://creativecommons.org/licenses/by/4.0/

\begin{abstract}
Onsite wastewater systems dispose of primary treated effluent by utilizing the soil for final recycling and renovation of wastewater into the environment. Soil and site limitations have become a challenge to design a wastewater system and dispose of onsite wastewater using a conventional pipe and gravel design. Using secondary-treated effluent from an advanced treatment unit applied to a reduced disposal area offers an additional alternative when developing an onsite wastewater system. The objective of this study was to determine the feasibility of hydraulically loading limiting soils with secondary-treated effluent in a reduced disposal area. A reduced disposal area was constructed at six existing residences within the same subdivision that had shallow redoximorphic features that precluded using a conventional pipe and gravel wastewater design. Each residence had an existing advanced treatment unit with a surface discharge of secondary-treated effluent. Flows were diverted from the surface discharge to the reduced disposal area. Wastewater flows were recorded at regular intervals, along with ponding depths in the disposal area and fluctuations in the seasonal water table over a 12-month period (March 2017 to March 2018). The disposal areas were hydraulically loaded at 2 to 3.8 times the rate recommended for secondary-treated effluent. Wastewater effluent was sampled throughout the study and resulted in a mean of $<8.5 \mathrm{mg} \cdot \mathrm{L}^{-1}$ total suspended solids, $<5.3 \mathrm{mg} \cdot \mathrm{L}^{-1}$ biochemical oxygen demand, and $>6.3 \mathrm{mg} \cdot \mathrm{L}^{-1}$ dissolved oxygen, all of which met or exceeded the minimum water quality criteria for surface discharges of secondary-treated effluent. Three of the six sites showed ponding depths between 0 and $4 \mathrm{~cm}$ in the trenches during the study period. The remaining three sites showed ponding between 0 and $35 \mathrm{~cm}$ in the trenches during the study period. Based on the results of this study, a reduced disposal area utilizing secondary-treated effluent appears to be a feasible option to surface discharging.
\end{abstract}




\section{Keywords}

On-Site Wastewater Disposal, Septic System, Effluent, Soil Renovation

\section{Introduction}

Managing household wastewater (i.e. effluent) by onsite disposal is critical to keeping rural areas and water sources free from disease and unsanitary living conditions. According to the 2017 Rural Profile of Arkansas, 42\% of the Arkansas population is classified as rural [1]. Consequently, rural dwellings in Arkansas that are not connected to a public sewer system must utilize an onsite wastewater system that relies on the soil to renovate household wastewater before the effluent is returned to the hydrologic cycle.

In 1977, the Arkansas General Assembly passed the Sewage Disposal Act 402. Act 402 defined the guidelines for handling domestic waste. Following Act 402, the Arkansas Department of Health adopted Rules and Regulations regarding onsite wastewater disposal [2]. The Rules and Regulations are referenced today and revised periodically with improved methods and technologies. Each day, wastewater from rural Arkansas homes and businesses is discharged into the soil where the effluent is renovated by filtering through the soil and recycled back into the environment using conventional onsite wastewater systems. The soil captures and clarifies the effluent from a wastewater system by removing nutrients, pathogens, and remaining suspended solids [3]. A soil disposal area is the most efficient and cost-effective method to dispose of wastewater. The daily discharge of wastewater into the soil over time, with little evidence of contaminants or unsanitary conditions, shows how efficient the soil can be in renovating wastewater. However, as Arkansans continue to develop more rural areas that require an onsite wastewater system, locating suitable soil to safely renovate wastewater has become a challenge due to limiting soils (i.e. shallow depth to bedrock, a shallow seasonal water table, or $>35 \%$ clay textures) or a limited suitable disposal area available on the property.

An unsewered property being considered for development with limiting soils that is not suitable for a conventional wastewater system is allowed to utilize an advanced treatment unit (ATU) to manage the wastewater output. Advanced treatment units generate secondary-treated effluent, which allows for dispersal to a drip disposal area utilizing the soil for final renovation or an ATU with an overland-flow discharge. Drip disposal may be considered in limiting soils, if the soils meet the minimum suitability requirements defined in the Arkansas Drip Rules and Regulations. The drip disposal tubing must be installed at a depth with at least $23 \mathrm{~cm}$ separation from bedrock and may not be installed in any seasonal water table [4]. An advantage is that drip disposal can be utilized in limiting soils where a conventional wastewater system cannot. Disadvantages to utilizing drip disposal include the requirements of an additional license to design 
and an additional license to install, unique equipment to properly install the drip disposal tubing and additional infrastructure (control panel, headworks box, etc.) to manage the automatic or continuous flushing of the drip disposal tubing. When the soils are too limiting for advanced treatment with drip disposal, overland flow surface discharge is another option to manage the wastewater. However, an advanced treatment unit with an overland flow surface discharge requires a lot size of at least 1.2 ha, minimum overland-flow setbacks from boundaries and neighboring homes and a National Pollutant Discharge Elimination System (NPDES) permit issued by the Arkansas Department of Environmental Quality (ADEQ). The investment in minimum land to meet overland-flow setbacks, the administrative requirements to maintain an NPDES permit and the environmental concerns associated with overland-flow discharging may place a burden on the homeowner. Limiting soils considered for development that cannot utilize an advanced treatment unit with drip disposal due to limitations of the soil, or cannot utilize an advanced treatment unit with an overland-flow surface discharge point due to minimum land requirements, are left with no other options to consider when developing a rural property.

Currently, there are no data to provide guidance for using the soil to renovate secondary-treated effluent in Arkansas. Arkansas has no loading rates defined for secondary-treated effluent. Tyler [5] defined secondary-treated effluent loading rates based on organic loading of $<30 \mathrm{mg} \cdot \mathrm{L}^{-1}$ of biological oxygen demand (BOD). Wastewater with low BOD levels was hypothesized to reduce pore clogging at the trench-soil interface. With reduced bio-mat formation, soils could be hydraulically loaded with secondary-treated effluent at a rate greater than primary-treated effluent. Therefore, the focus of this study was to investigate the impact of hydraulically loading secondary-treated effluent into soils that are too limiting for a conventional wastewater system or an advanced treatment unit with drip disposal. This study also considered soils that are not limiting, but have a reduced disposal area. Exploring an alternative method for managing secondary-treated effluent disposal may reduce the need for an overland-flow NPDES permit, safely disperse secondary-treated effluent back into the hydrologic cycle, and provide development options as homeowners continue to move into rural areas that require an onsite wastewater system. It was hypothesized that limiting soils hydraulically loaded at two times the loading rate defined by Tyler [5] with secondary-treated effluent will not exceed a ponding depth of 27 $\mathrm{cm}$ for a consecutive period greater than 14 days in any disposal trench. It was also hypothesized that the performance of a reduced shallow disposal field will differ over time, specifically between wet and dry seasons.

\section{Materials and Methods}

\subsection{Site Description}

Six individual homeowners were selected in 2016 within a 64-ha area of a single sub-division in Saline County, Arkansas (Figure 1). The homeowners were 


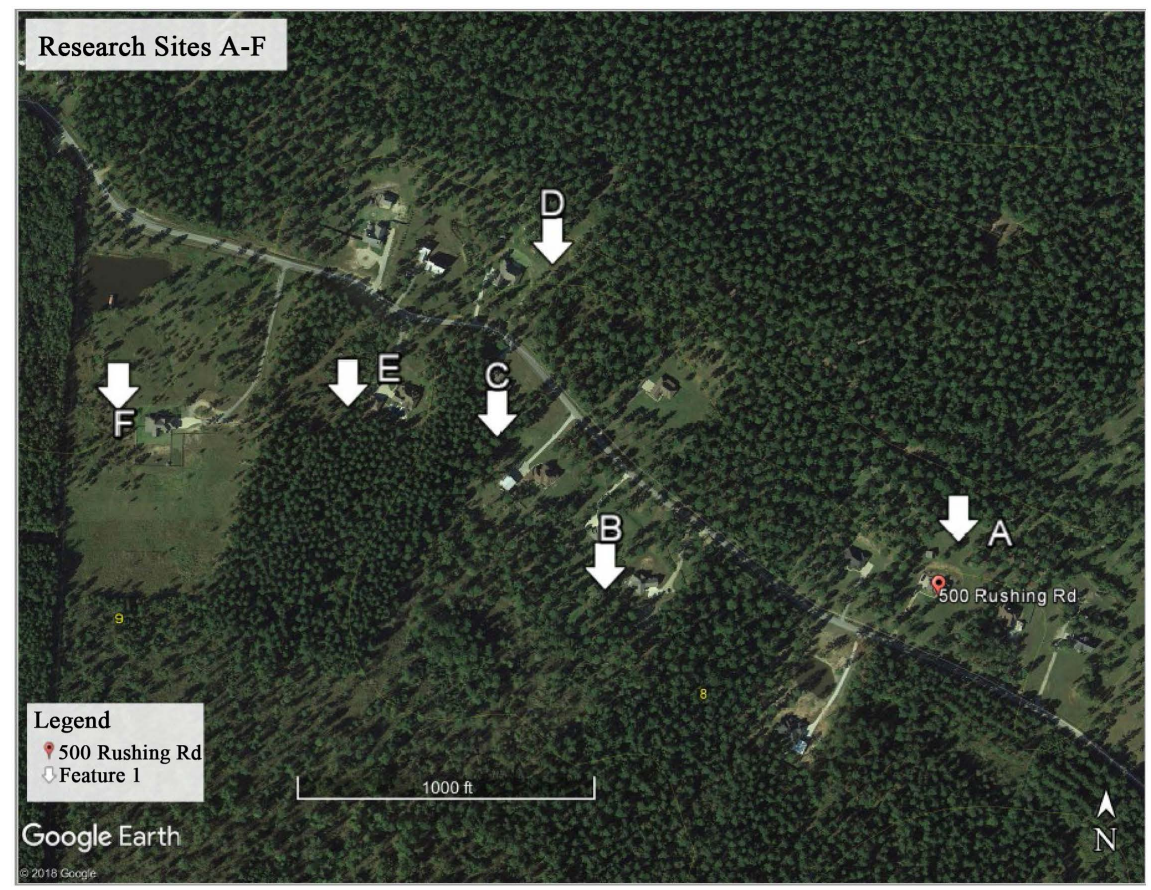

Figure 1. Aerial image of research Sites A through F in Saline County, Arkansas. Google Earth image created on February 26, 2019 [8].

willing cooperators whose lots were all within close proximity to one another and on similar, limiting soils for a traditional drainfield that ranged in size from 1.2 to 4.8 -ha. The homes had between three and four bedrooms and had between two and six occupants throughout the duration of this study.

The study area, and six homes within the study area, resides in the thermic soil temperature regime within the Ouachita Mountains, Major Land Resource Area (MLRA) 119 [6]. The mean annual air temperature in the region is $17^{\circ} \mathrm{C}$, while the mean annual precipitation ranges between 122 and $140 \mathrm{~cm}$ [7]. Within the research sites, the soils are typically shallow to weathered shale and have argillic soil horizons that begin between 30 and $36 \mathrm{~cm}$ from the surface, where both shallow bedrock and argillic horizon presence can restrict water flow through the soil profile.

For four of the six sites, the soils are mapped as a Carnasaw-Townley association (fine, mixed, semiactive, thermic, Typic Hapludults) with no mounds present. Based on visual assessment, the soils present at these four sites had shallow seasonal water tables, as evidenced by redoximorphic depletions present to the soil surface. At the remaining two sites, the soils are mapped as a Caddo-Messer complex (fine-silty, siliceous, semi-active, thermic, Typic Glossaqualfs) with mounds present. Based on visual observation, the soils between the mounds had shallow seasonal water tables, as evidenced by redoximorphic depletions present to the soil surface, while the soils associated within the mounds had seasonal water tables evident by redoximorphic features beginning at approximately the $55-\mathrm{cm}$ depth from the soil surface. However, based on the estimated volume of household wastewater produced at the two mounded sites, the 
amount of disposal area required by current Arkansas Rules and Regulations [2], and based on redoximorphic features present, the area associated with the mounds was inadequate for a conventional disposal area. Therefore, all six sites had limiting soils due to shallow water tables (four sites) and/or had insufficient area of suitable soil (two sites) for a conventional wastewater system. As an alternative to the conventional wastewater system (i.e. septic tank, distribution box, and a disposal field), the Rules and Regulations for onsite wastewater disposal in $\mathrm{Ar}$ kansas [2] allow sites with limiting soils or disposal areas to utilize an advanced treatment unit to renovate household wastewater before discharging to an overland-flow point on the soil surface.

All six research sites utilized an advanced treatment unit manufactured by Orenco Systems (Model AX20-RT mode 1B, Sutherlin, OR) or Bio-Microbics, Inc. (Model MicoFAST 0.5, Lenexa, KS). Both types of units consisted of a settling compartment, a secondary-treatment compartment, and final compartment for ultraviolet (UV) disinfection and sampling. The advanced treatment units produce a quality of wastewater that is acceptable to discharge onto the soil surface, which is effluent containing $10 \mathrm{mg} \cdot \mathrm{L}^{-1}$ or less biochemical oxygen demand (BOD), $15 \mathrm{mg} \cdot \mathrm{L}^{-1}$ or less total suspended solids (TSS), $6 \mathrm{mg} \cdot \mathrm{L}^{-1}$ or greater dissolved oxygen (DO), and a $\mathrm{pH}$ between 6.0 and 9.0 [9]. Consequently, each landowner in this study has a NPDES permit to surface-discharge their household wastewater after passing through the advanced treatment unit. Homeowners agreed to allow an experimental shallow-drain-field system to be installed on their property and to be studied to potentially find an alternative disposal method to surface discharging.

\subsection{Treatments and Experimental Design}

Among the six sites, two sites had experimental shallow-drain-field systems installed into the mounds that were present, while the other four sites, which had no mounds, had experimental shallow-drain-field systems installed on contour with the natural slope. Secondary-treated effluent loading rates were derived based on the soil texture at the most-limiting layer with guidance from previous loading rates derived for secondary-treated effluent [3]. The initial loading rates for the non-mounded $\left(12.2 \mathrm{~L} \cdot \mathrm{m}^{-2} \cdot \mathrm{d}^{-1}\right)$ and mounded sites $\left(32.5 \mathrm{~L} \cdot \mathrm{m}^{-2} \cdot \mathrm{d}^{-1}\right)$ were doubled for both the non-mounded and mounded disposal sites (24.4 and 65.0 $\mathrm{L} \cdot \mathrm{m}^{-2} \cdot \mathrm{d}^{-1}$, respectively). The six sites had similar site characteristics, including similar soil map units, soil profile textures, slopes, landscape positions, and other soil morphological characteristics (Table 1).

\subsection{Site Evaluation and Disposal Site Construction}

The initial three-month phase of this research project (September 2016 to December 2016) consisted of determining appropriate disposal areas, evaluating the soils to be studied, and installing the new shallow-disposal areas at each site. Since each research area was to exist on an individual's property, careful consideration was given to the homeowner preference for location of each disposal 
Table 1. Summary of soil and landscape characteristics and soil limitations for each of the six research sites.

\begin{tabular}{|c|c|c|c|c|c|c|}
\hline Site & Map Unit & Texture & Slope (\%) & Site Type & Slope Position & Limitation \\
\hline A & Carnasaw $^{\mathrm{a}}$, steep & Sandy clay loam & 3 & Non-mounded & Backslope & Seasonal water table \\
\hline B & Caddo, complex & Loam & 5 & Mound & Backslope & Disposal area \\
\hline $\mathrm{C}$ & Caddo, complex & Loam & 5 & Mound & Backslope & Disposal area \\
\hline $\mathrm{D}$ & Carnasaw $^{\mathrm{b}}$, steep & Sandy clay loam & 3 & Non-mounded & Backslope & Seasonal water table \\
\hline $\mathrm{E}$ & Carnasaw undulating & Sandy clay loam & 2 & Non-mounded & Backslope & Seasonal water table \\
\hline $\mathrm{F}$ & Carnasaw, steep & Sandy clay loam & 4 & Non-mounded & Backslope & Seasonal water table \\
\hline
\end{tabular}

${ }^{a}$ Fine, mixed, semi-active, thermic Typic Hapludults; ${ }^{b}$ Fine-silty, siliceous, active, thermic Typic Glossaqualfs.

area. Once an acceptable disposal area location was determined, one soil pit per site was excavated to an approximate depth of $120 \mathrm{~cm}$ in each of the defined disposal areas to evaluate the soil profile characteristics and establish a hydraulic loading rate. Soil descriptions were prepared for each horizon to a depth of 120 $\mathrm{cm}$, recording information such as the texture by feel, estimated coarse fragment concentration (estimated to be $40 \%$ ) in the upper $30 \mathrm{~cm}$, moist matrix Munsell color, and redoximorphic feature (i.e. concentrations and depletions) presence and abundance. Representative soil samples were collected from each horizon for soil particle-size analyses using a modified 12-hr hydrometer method [10] after oven drying for 48 hours at $70^{\circ} \mathrm{C}$ and grinding and sieving sub-samples through a $2-\mathrm{mm}$ screen.

Four disposal trenches were excavated at each site with a rubber-tracked 4500 $\mathrm{kg}$ track hoe. Disposal trenches were 21-m long, 35-cm deep, 45-cm wide, spaced $1.2 \mathrm{~m}$ center to center (Figure 2(a)), and disposal trenches were installed following the contour (i.e. the same elevation on the trench bottom along the length of a trench). Disposal trenches were backfilled with a $20-\mathrm{cm}$ thick bed of commercially available, washed, crushed gravel, $2.5 \mathrm{~cm}$ in diameter or less. A low-pressure distribution network was constructed from 1.9-cm-diameter polyvinyl chloride (PVC), Schedule-40 pipe and installed in the center of each disposal trench atop the crushed-gravel bed (Figure 2(b)). Holes, $0.32 \mathrm{~cm}$ in diameter, were drilled every $120 \mathrm{~cm}$ and protective orifice shields (STF-106TDS, SIM/TECH, Boyne City, MI) were snapped over each hole. Geotextile fabric (2624RB $24 \times 300$, Advanced Drainage Systems, Hilliard, OH) was cut to a $45-\mathrm{cm}$ width and laid over the low-pressure distribution network and gravel bed. The gravel and pipes were then covered with $15 \mathrm{~cm}$ of native soil, with slight mounding over the disposal trench to allow for settling over time.

A $1.6-\mathrm{cm} \times 1.9-\mathrm{cm}$ flow meter (MMPD Oscillating piston meter, Master Meter, Mansfield, TX) was installed at the supply line entering the upper-most disposal trench to measure flows (Figure 2(c)). Polyvinyl chloride socket-gate valves, $2.67-\mathrm{cm}$ diameter, were installed at the in-flow end of each lateral line for squirt height adjustment (Figure 2(d)), where squirt height is a common visual assessment conducted to verify equal distribution in the low-pressure network of pipes. The gate valves allowed for adjustments to be made to make flows equal 


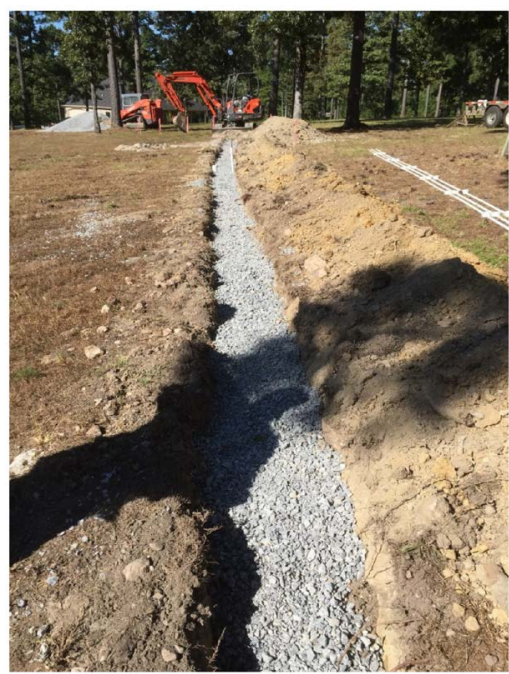

(a)

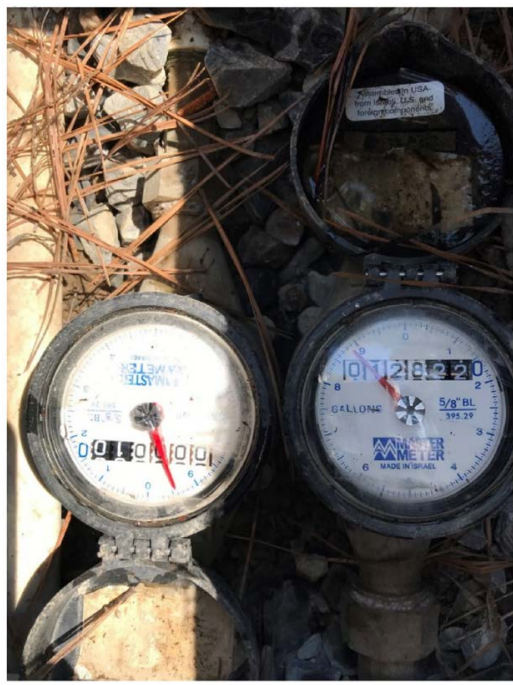

(c)

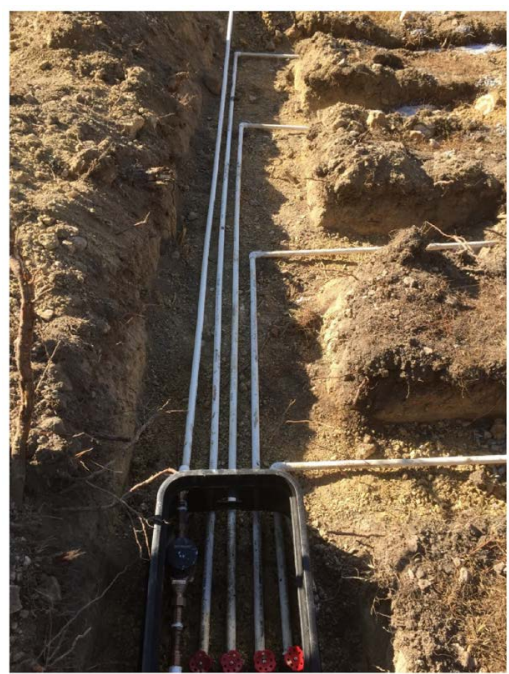

(b)

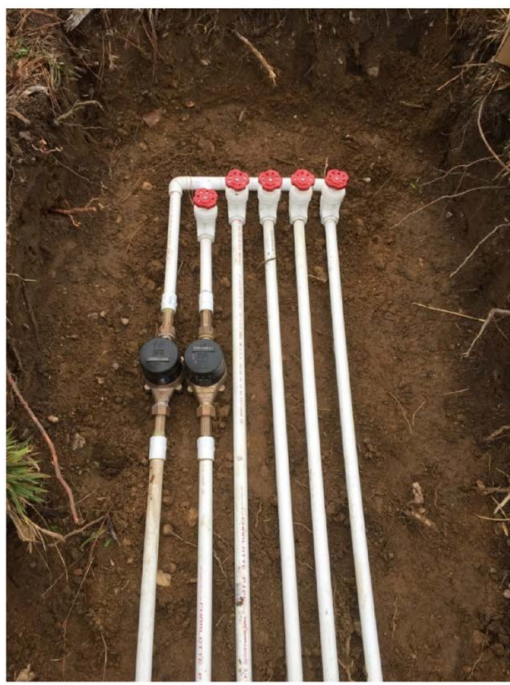

(d)

Figure 2. Disposal-area trench line 1 of 4 at research Site A that has been excavated and filled with gravel (a); Image of the low-pressure distribution network installed at Site A to control and deliver secondary-treated effluent to the four disposal lines (b); Image of flow meters installed at each research site to record the flow of secondary-treated effluent into the disposal area (c); Image of gate valves installed at Site E. Gate valves were used to regulate squirt height across the disposal area for even distribution (d).

for each disposal trench. The gate valves were enclosed in a water meter box for easy access and adjustment when necessary. Polyvinyl chloride electrical flush sweeps, $2.67 \mathrm{~cm}$ in diameter with $2.67-\mathrm{cm}$-diameter female adapters and threaded plugs, were installed at the end of each lateral line for maintenance and to facilitate visual assessment of squirt heights (Figure 3(a)). The flush sweeps were also installed in a water meter box for access.

In-trench monitoring ports, consisting of 8.9-cm diameter PVC pipe, were installed vertically in the middle of each disposal trench. Four slits, approximately $0.3-\mathrm{cm}$ wide and $20-\mathrm{cm}$ long, were cut vertically from the bottom up. The slits 


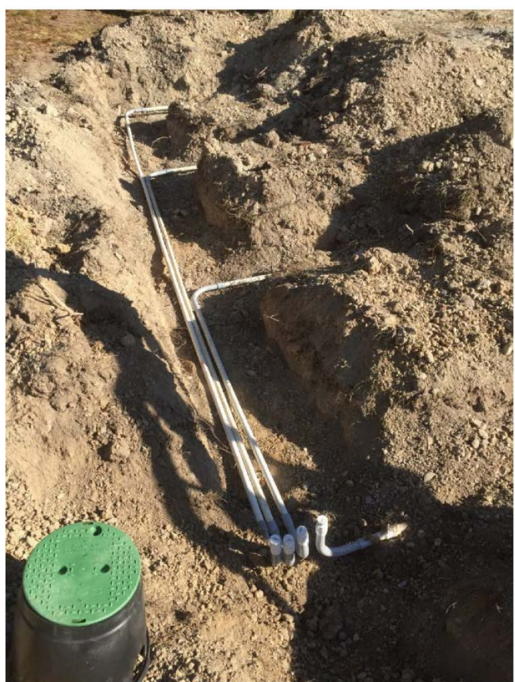

(a)

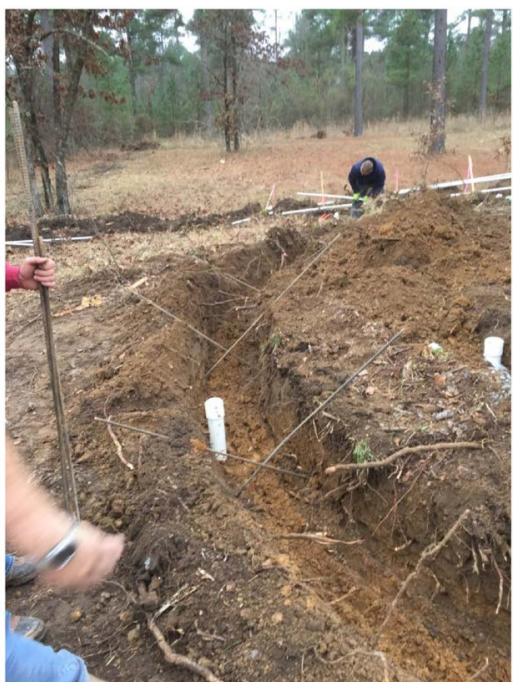

(b)

Figure 3. Image of the flush sweeps installed at Site A (a). Flush sweeps allow for squirt-height measurement and the ability to flush the low-pressure distribution network. Image of an in-trench monitoring port being installed at Site B (b). Site B was one of the mound disposal areas. The inspection port is used to measure ponding depths within the disposal trench. Each trench has its own monitoring port.

allowed for the soil solution to equilibrate inside the monitoring port so the depth from the soil surface to free solution (i.e. solution ponding) inside the trench could be measured (Figure 3(b)).

An observation port, also consisting of 8.9-cm-diameter PVC pipe, was installed vertically to a depth of $60 \mathrm{~cm}$ approximately $1.5 \mathrm{~m}$ up-slope from the disposal area to allow for observation and measurement of the seasonal water table. Four slits, approximately $0.3-\mathrm{cm}$ wide and $20-\mathrm{cm}$ long, were cut vertically from the bottom up. The slits allowed free water to flow into the observation port to facilitate measurement of the depth to free water from the soil surface. When construction of each site was complete, the surface was manually seeded with a rye (Lolium spp.)-Bermudagrass (Cynodon dactylon) mixture at an approximate rate of $180-\mathrm{kg}$ seed $\mathrm{ha}^{-1}$ and the seeded area was covered with straw to prevent erosion.

Each research site was connected to the homeowner's advanced treatment unit. Soil texture, determined during initial assessment of the disposal area, was used to set an expected effluent loading rate. The flow coming into the disposal site was recorded by reading the flow meter between observations and minor changes were made in the first month of the study by diverting excess flows or by turning off disposal trenches due to inadequate flows. Once the target effluent loading rate was achieved, no adjustments were made for the remainder of the study.

\subsection{Effluent Source and Characterization}

The secondary-treated effluent used to hydraulically load the shallow-disposal 
area came directly from the homeowners' advanced treatment unit via a pump and supply line. The overland-flow discharge point was re-rerouted to the study disposal area. A single-stage effluent pump or a turbine pump was used to supply effluent to the shallow drain fields. A control panel capable of time-dosing the secondary-treated effluent in small amounts throughout the day was used. Thus, each research site had secondary-treated effluent delivered in small, timed doses (Table 2), evenly distributed to the disposal site by the low-pressure distribution network.

Requiring the limiting soil profile to accept and transport primary-treated effluent may have complicated the study by the formation of a biomat or possible surfacing during the study causing an environmental concern. For this reason, the secondary-treated effluent was sampled and characterized every six months. Four grab samples were collected between September 2016 and September 2018 by a Class II wastewater operator and processed by a third-party laboratory (Environmental Services, West Markham, Little Rock, AR) for effluent characteristics, namely BOD, TSS, DO, and $\mathrm{pH}$.

\subsection{Disposal Site Monitoring}

Monitoring of the disposal areas consisted of recording flows into each disposal area, the depth to free solution in each disposal trench, the depth to free water in the observation well, overall site conditions, and rainfall amounts. Disposal-site monitoring occurred at 14-day intervals over the 14-month research period (i.e. January 2017 to March 2018). Flows at each disposal site were recorded at the flow meter. The reading was recorded in written format and a digital picture was taken. Flows were compared against public water bill usage, which confirmed measured flows to each disposal site were reasonable. A hand-held tape measure was used to record ponding depths in the disposal trenches. Measurements were made from the downslope lip of the in-trench monitoring port to the top of the ponded-solution surface, if present. A tape measure was also used to record the

Table 2. Summary of the dosing frequency used for disposal at research Sites A through F. Each of the sites listed have logic in the control panel to override time-dose settings in the event of a high-level event.

\begin{tabular}{|c|c|c|c|c|c|c|}
\hline Site & $\begin{array}{c}\text { Working } \\
\text { Volume }^{\mathrm{a}}(\mathrm{L})\end{array}$ & $\begin{array}{l}\text { Minimum Dose } \\
\text { to Pressurize }{ }^{b}(L)\end{array}$ & $\begin{array}{c}\text { Daily Flow } \\
\text { Average }^{c}(\mathrm{~L})\end{array}$ & $\begin{array}{l}\text { Pump Flow Rate } \\
\quad\left(\mathrm{L} \mathrm{min}^{-1}\right)\end{array}$ & $\begin{array}{l}\text { Timer On }{ }^{e} \\
\quad(\min )\end{array}$ & $\begin{array}{l}\text { Timer Off } \\
\text { (min) }\end{array}$ \\
\hline A & 132 & 32 & 1749 & 189 & 0.50 & 80 \\
\hline B & 378 & 9.5 & 863 & 105 & 0.75 & 130 \\
\hline C & 378 & 9.5 & 458 & 105 & 0.75 & 240 \\
\hline $\mathrm{D}$ & 378 & 9.5 & 488 & 105 & 0.75 & 240 \\
\hline $\mathrm{E}$ & 132 & 24 & 697 & 113 & 0.50 & 120 \\
\hline $\mathrm{F}$ & 378 & 24 & 772 & 105 & 0.75 & 144 \\
\hline
\end{tabular}

${ }^{a}$ Working volume is the amount of storage in the dose tank utilized to level the daily flow; ${ }^{\mathrm{b}}$ Minimum dose to pressurize is the amount of secondary-treated effluent required to fill the lateral pressure distribution infrastructure; ${ }^{\circ}$ Daily flow average represents the average daily flow during the study period; ${ }^{\mathrm{d}}$ Pump

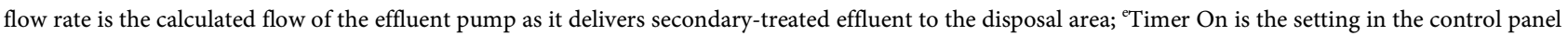
that tells the discharge pump to run for a specific period of time; ${ }^{\mathrm{f}}$ Timer Off is the setting in the control panel that tells the discharge pump how long to rest. 
depth to free water in the observation ports. Measurements were made from the downslope lip of the top of the observation port to top of the free-water surface, if present. During each site visit, signs of disposal-site stress, unique vegetation, and any other unique observations were also noted.

Rainfall was measured at Site A using a rain collection gauge made by Davis Instruments (model Vantage Vue, Davis Instruments, Hayward, CA) from September 2016 through January 2017. Rainfall data recorded at Site A were compared to rainfall data recorded within the research area that was publicly available through the Farm Logs web application [11]. The Farm Logs rainfall history and tracking came from a dataset that the National Oceanic and Atmospheric Administration (NOAA) produced. The NOAA sources data from multiple radar and ground stations within the county to algorithmically calculate the amount of precipitation that falls on a high-resolution grid across the continental United States. The NOAA factors in variables like wind and terrain that influence where the rain actually hits the ground, which was done within $1 \mathrm{~km}(0.6$ mi) of accuracy [12]. Rainfall amounts reported through the Farm Logs application were determined to be accurate when compared to the actual on-site measurements. Farm Logs rainfall data were used for the remainder of the study period after January 2017.

\subsection{Disposal Site Failure Criteria}

Disposal site failure criteria have previously been based on the presence of a certain amount of solution storage in a trench for an extended period of time [13] [14], as the disposal field trench is designed to facilitate dispersal of effluent into the soil rather than for storage. Based on guidance from several previous reports [13] [14] [15], for the purposes of this study, if any disposal trench in a disposal area had a solution ponding depth in excess of $27 \mathrm{~cm}$, which was $8 \mathrm{~cm}$ from the soil surface, for two or more consecutive 14-day measurement intervals, the disposal trench was noted as an exceedance.

\subsection{Data Analyses}

In-trench and observation well ponding depths were plotted over time. Temporal trends in in-trench ponding depths among active, effluent-receiving lines at each site were visually assessed relative to the soil surface, depth of the gravel, and depth of the bottom of the trench and for the frequency of in-trench ponding exceeding the depth to the in-trench gravel. Temporal trends of ponding depths in the observation wells were also visually assessed. In addition to visually assessing temporal trends in ponding depths, analysis of variance was conducted separately by site, using all temporal measurements as replications, using Minitab (version 13.31, Minitab, Inc., State College, PA) to evaluate differences in mean ponding depths over time among trench lines. Similar to Prater et al. [16] and Gibbons et al. [15], linear regression analyses were also conducted using Minitab, separately by trench line, to formally evaluate the temporal trend in ponding depths over time (i.e. whether ponding depths were increasing, de- 
creasing, or not changing over time), as an increasing trend in mean ponding depth over time would indicate improper and undesired on-site system behavior. Significance was judged at $P<0.05$ for all analyses.

\section{Results and Discussion}

\subsection{Effluent Characteristics}

A prerequisite to studying a reduced drainfield in a limiting soil profile was to utilize secondary-treated effluent capable of meeting minimum overland-flow discharge requirements as defined by the Arkansas Department of Environmental Quality [9]. The basic premise of using secondary-treated effluent in the study was to minimize the formation of a biomat by managing effluent with low BOD and TSS and large enough DO and, if surface ponding occurred, the environmental impact would be negligible. Samples collected among the research sites from April 2017 through April 2018 had a mean of $5.3 \mathrm{mg} \cdot \mathrm{L}^{-1}$ BOD, 8.5 $\mathrm{mg} \cdot \mathrm{L}^{-1} \mathrm{TSS}, 6.3 \mathrm{mg} \cdot \mathrm{L}^{-1} \mathrm{DO}$, and $7.4 \mathrm{pH}$. Consequently, the secondary-treatment water quality met or exceeded minimum secondary-treated surface discharge standards [9].

\subsection{Rainfall Characteristics}

Rainfall during the study period had a direct impact on the performance of the reduced drainfield in limiting soils (Figure 4). Rainfall measurements from March through July 2017 and December 2017 through March 2018 indicated $38 \%$ more rainfall than the 30-year normal. However, rainfall from August through November 2017 indicated 53\% less rainfall than the 30-year normal. Data collected during the above-average rainfall periods provided information on how a reduced drainfield in limiting soils would react during hydrologically stressed conditions, as well as how the reduced drainfield would react during below-average rainfall conditions.

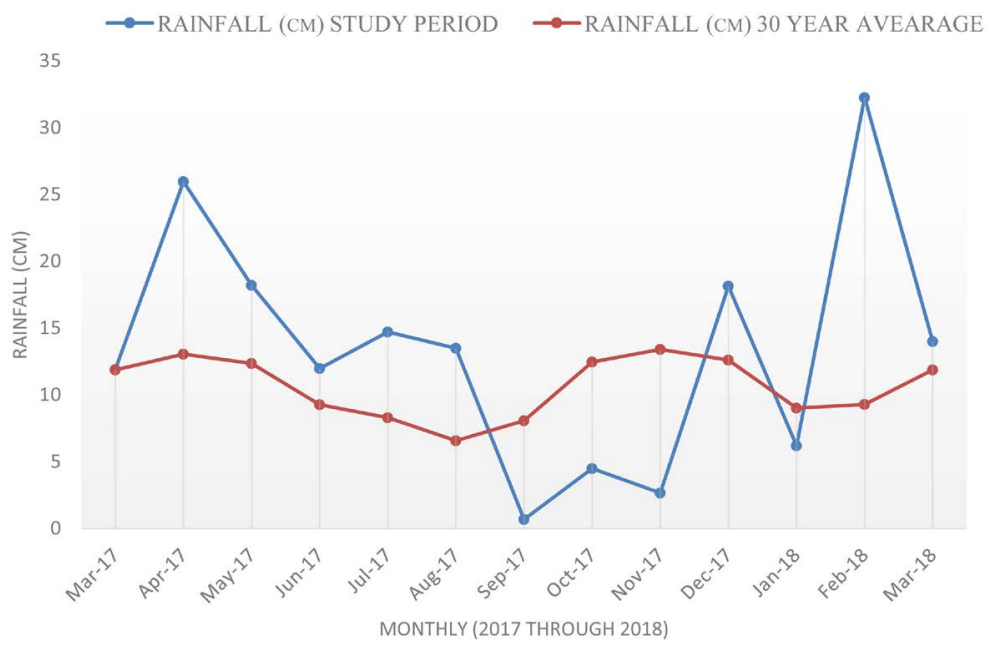

Figure 4. Monthly rainfall data, both actual and 30-year (1981-2010) average amounts associated within the study area. 


\subsection{Non-Mounded Sites}

\subsubsection{Seasonal Water Table Impacts on Ponding Depths}

Soil characteristics in the four non-mounded sites indicated the presence of a shallow seasonal water table. The A horizon, with a 10YR 2/2 matrix color, and the E horizon, with a 10YR 3/3 matrix color, provided evidence the seasonal water table rise and fall had caused reduction in the soil profile at the same proposed depth as the disposal trenches being studied. However, exactly how the fluctuating seasonal water table impacted the ability of the disposal area to accept daily doses of secondary-treated effluent was unknown.

Among the four non-mounded sites, the seasonal water table depths, as measured in the observation ports up-slope of the upper-most disposal trench, ranged from 25 to $>80 \mathrm{~cm}$ from the surface (Figure 5). For the wet period of March through July 2017, the seasonal water table was recorded between 25 and $80 \mathrm{~cm}$ from the surface at Site A, D, E, and F compared to ponding depths in the disposal trenches, as measured by the monitoring ports within the disposal trenches themselves, recorded between 0 and $39 \mathrm{~cm}$ from the surface (Figure 6 and Figure 7). For the dry period of August through November 2017, the seasonal water table was recorded at 65 to $>80 \mathrm{~cm}$ from the surface at Sites A, D, E, and $\mathrm{F}$ compared to the ponding depths in the disposal trenches of 8 to $>39 \mathrm{~cm}$ from the surface (Figure 8 and Figure 9).

Measurements of the seasonal water table depths correlated with rain events and impacted ponding depths in the disposal trenches (Figure 10). Rain events

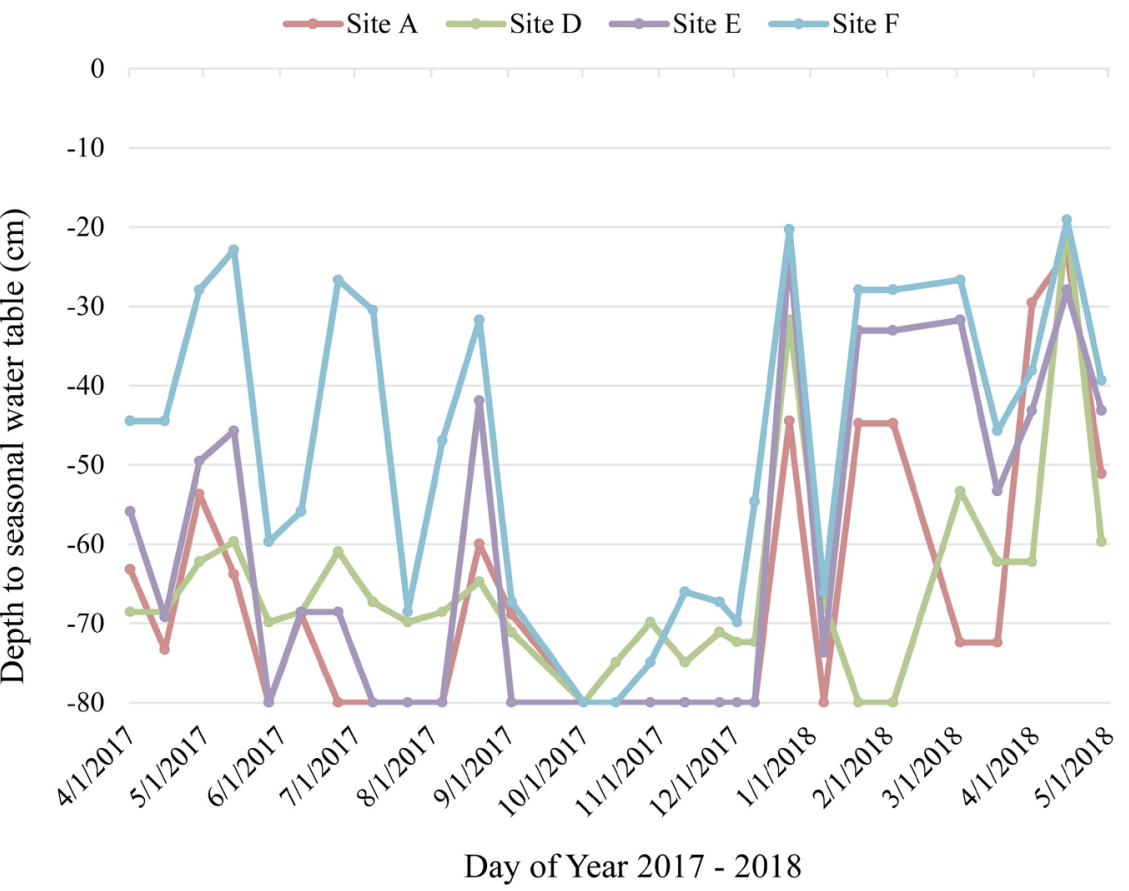

Figure 5. Seasonal water table fluctuations from April 2017 to May 2018 from the up-slope observation port at research Sites A, D, E, and F. No water table was measured for Sites B and C. The soil surface is the $0-\mathrm{cm}$ line on the $\mathrm{y}$-axis. The bottom of the observation well is at the $-80-\mathrm{cm}$ line depth. 


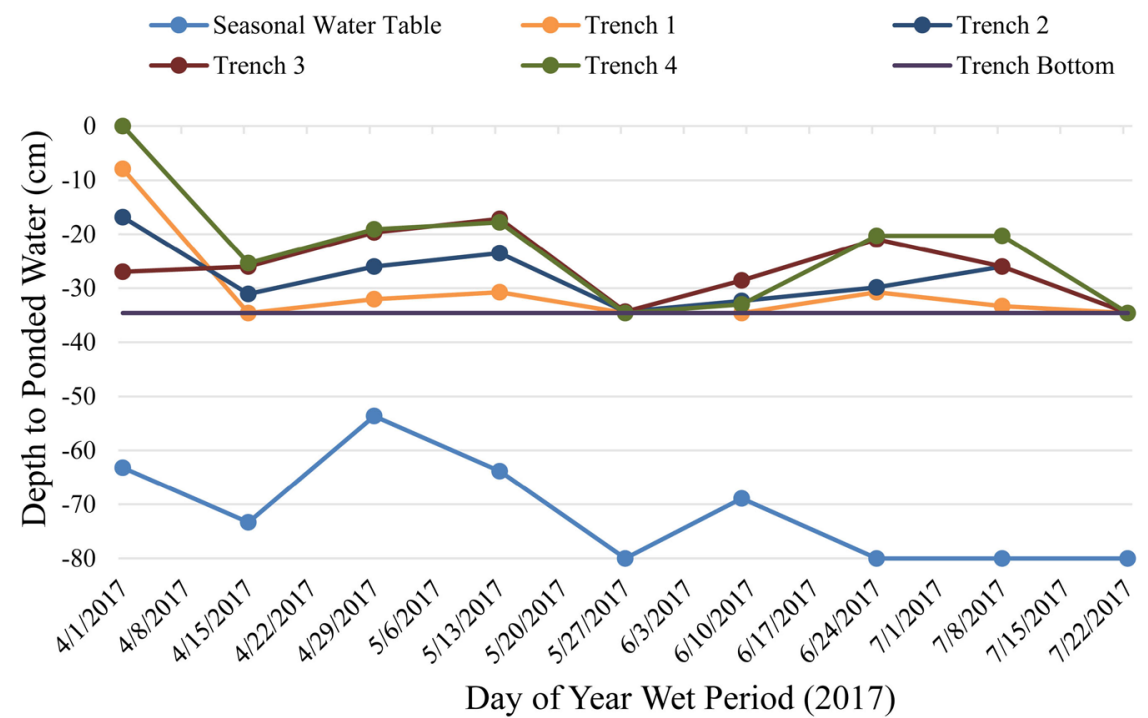

(a)

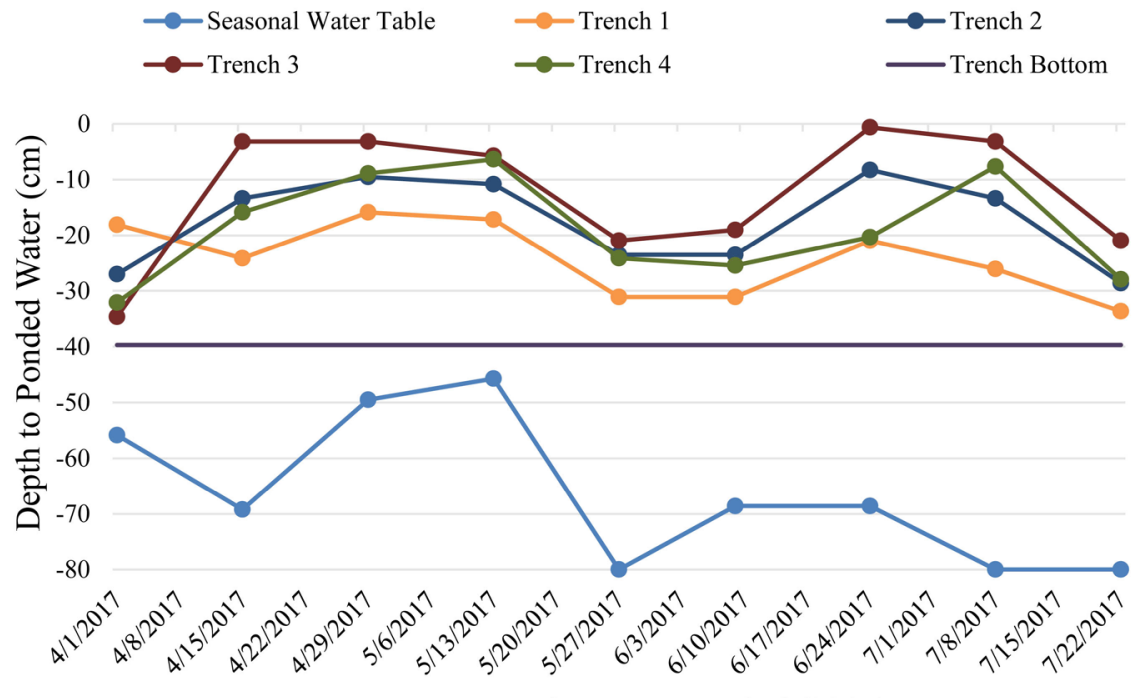

Day of Year Wet Period (2017)

(b)

Figure 6. Depth to ponded secondary-treated effluent during the wet period of April to July 2017 from the up-slope observation port and the four disposal trenches at research Site A (a) and Site E (b). The soil surface is the 0 -cm mark on the y-axis. The trench bottom is at the $35-\mathrm{cm}$ depth mark.

and corresponding seasonal water table fluctuations accounted for 19 exceedances of a total of 116 observations (16\%) between April 2017 and April 2018. An interceptor drain installed up-slope from the disposal area could be used to divert the seasonally shallow water table and may have alleviated a portion of the hydrologic stress to the disposal area at each site.

\subsubsection{Peak Flows}

Each non-mounded disposal site studied had existing infrastructure in place that included a 946-L dose chamber. The size of the dose chamber was adequate for 


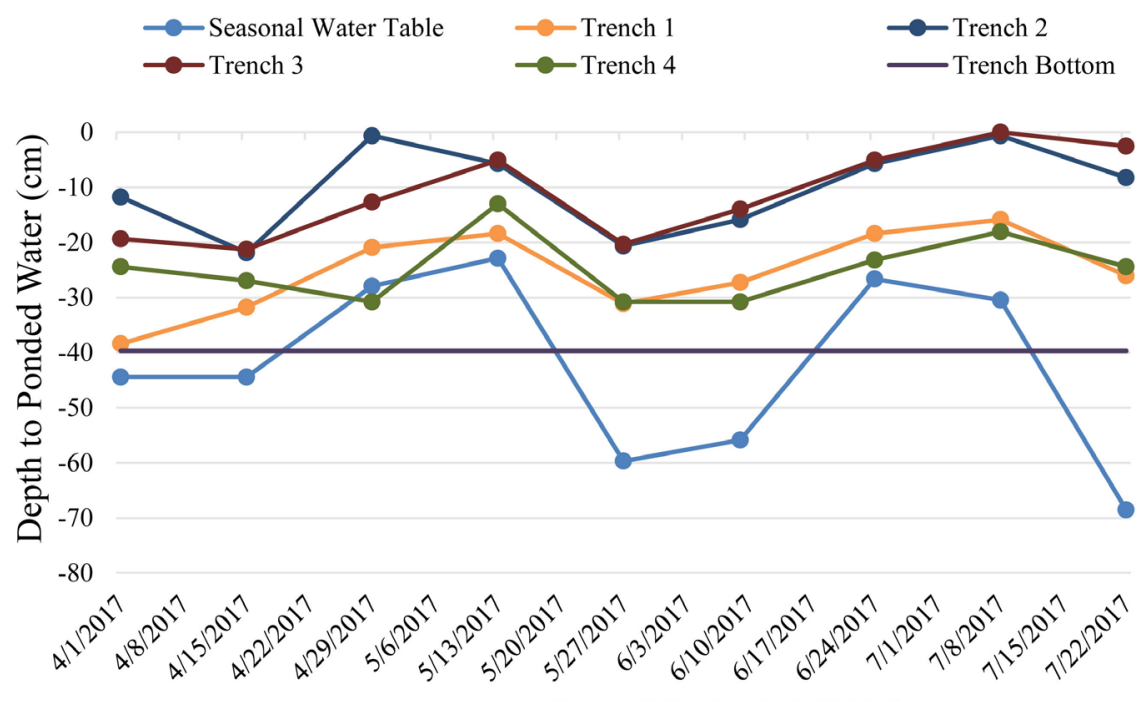

Day of Year Wet Period (2017)

(a)

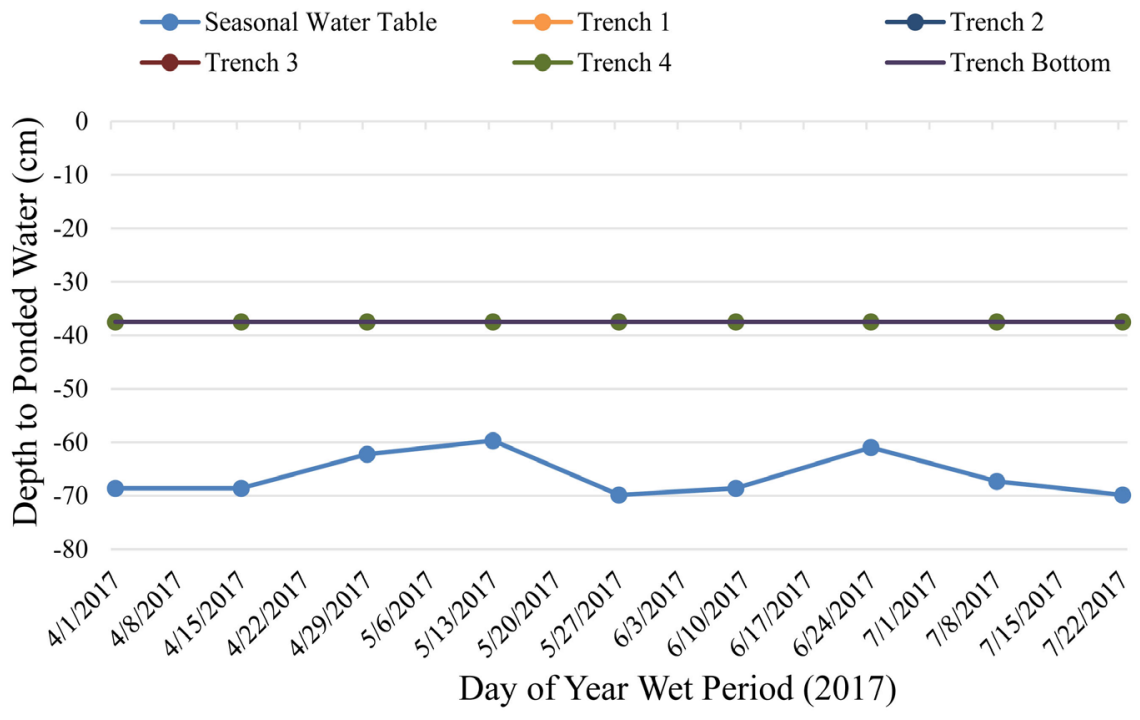

(b)

Figure 7. Depth to ponded secondary-treated effluent during the wet period from April to July 2017 from the up-slope observation port and the four disposal trenches at research Site F (a) and Site D (b). The soil surface is the 0 - $\mathrm{cm}$ mark on the $\mathrm{y}$-axis. The trench bottom is at the $40-\mathrm{cm}$ depth mark for Site F and the $37-\mathrm{cm}$ depth mark for Site D. No ponding was measured during the study period at Site D; however, the seasonal water table was present throughout this period.

dosing secondary-treated effluent to an overland-flow point. However, dosing secondary-treated effluent to a reduced disposal area would have benefited from having a larger dose tank. A larger dose tank would have allowed for improved equalization during peak-flow events. Site F changed ownership in December 2017 and one of the exceedances recorded was due to peak flows caused by excess laundry cycles on the move-in weekend. A larger dose chamber to store and equalize the flow throughout the day could have prevented the exceedance. 


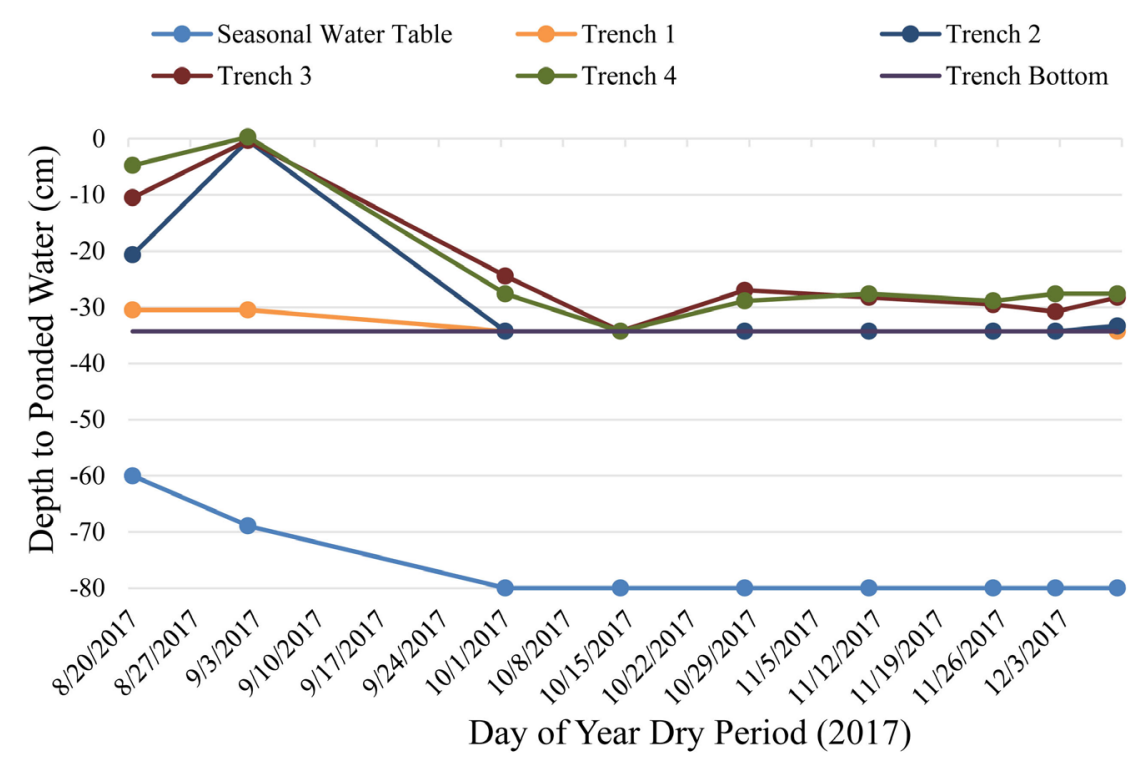

(a)

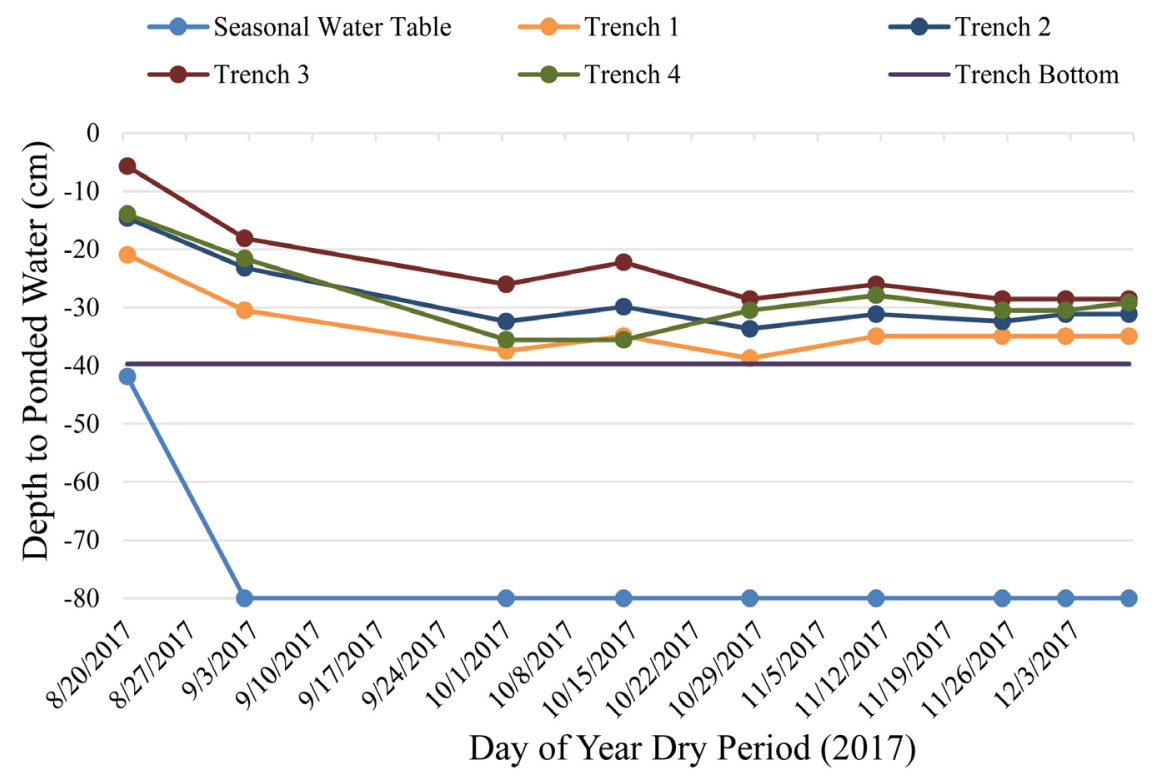

(b)

Figure 8. Depth to ponded secondary-treated effluent during the dry period from August to December 2017 from the up-slope observation port and the four disposal trenches at research Site A (a) and Site E (b). The soil surface is the 0 -cm mark on the y-axis. The trench bottom is at the $34-\mathrm{cm}$ depth mark for Site A and the $40-\mathrm{cm}$ depth mark for Site E.

\subsubsection{Size of Disposal Areas}

The non-mounded disposal areas that received secondary-treated effluent covered $78 \mathrm{~m}^{2}$, where each site had four lines that were $21.3-\mathrm{m}$ long on $1.2-\mathrm{m}$ centers. The redoximorphic features of the soil in the non-mounded sites had no corresponding loading rate in the Arkansas Rules and Regulations [2] to compare a similar disposal area using primary-treated effluent. However, if a loading rate of $8.4 \mathrm{~L} \cdot \mathrm{m}^{-2} \cdot \mathrm{d}^{-1}$ [5] was assumed based on the soil texture of the most-limiting horizon (i.e. a clay-textured horizon at some relatively shallow depth at all sites), 


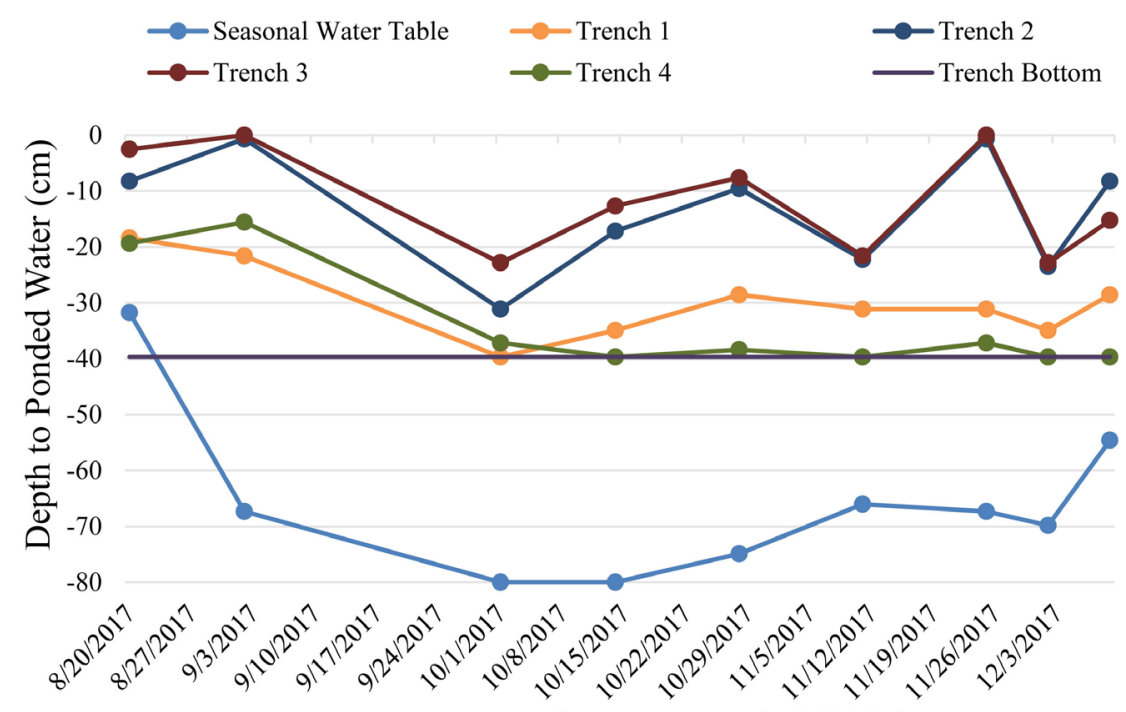

Day of Year Dry Period (2017)

(a)

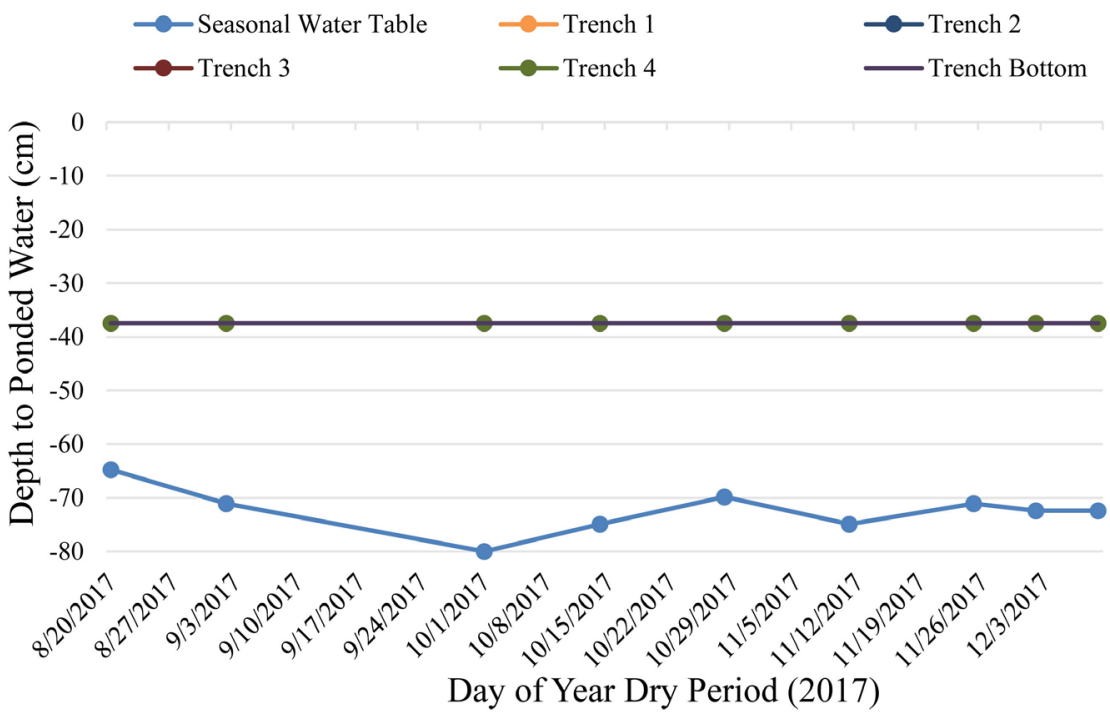

(b)

Figure 9. Depth to ponded secondary-treated effluent during the dry period from August to December 2017 from the up-slope observation port and the four disposal trenches at research Site F (a) and Site D (b). The soil surface is the 0 - $\mathrm{cm}$ mark on the y-axis. The trench bottom is at the $40-\mathrm{cm}$ depth mark for Site F and the 37-cm depth mark for Site D. No ponding was recorded in any trench during this period at Site D; however, the seasonal water table was present throughout the study period.

and a standard trench spacing of 2.4-m was used, the disposal area required would have been $372-\mathrm{m}^{2}$ using primary-treated effluent. Utilizing secondary-treated effluent in a reduced disposal area that occupied only $21 \%$ of the area required for primary-treated effluent was a significant area reduction when contemplating an alternative method to disposing of secondary-treated effluent other than by overland-flow surface discharging or when the suitable area for disposal is greatly limited. 

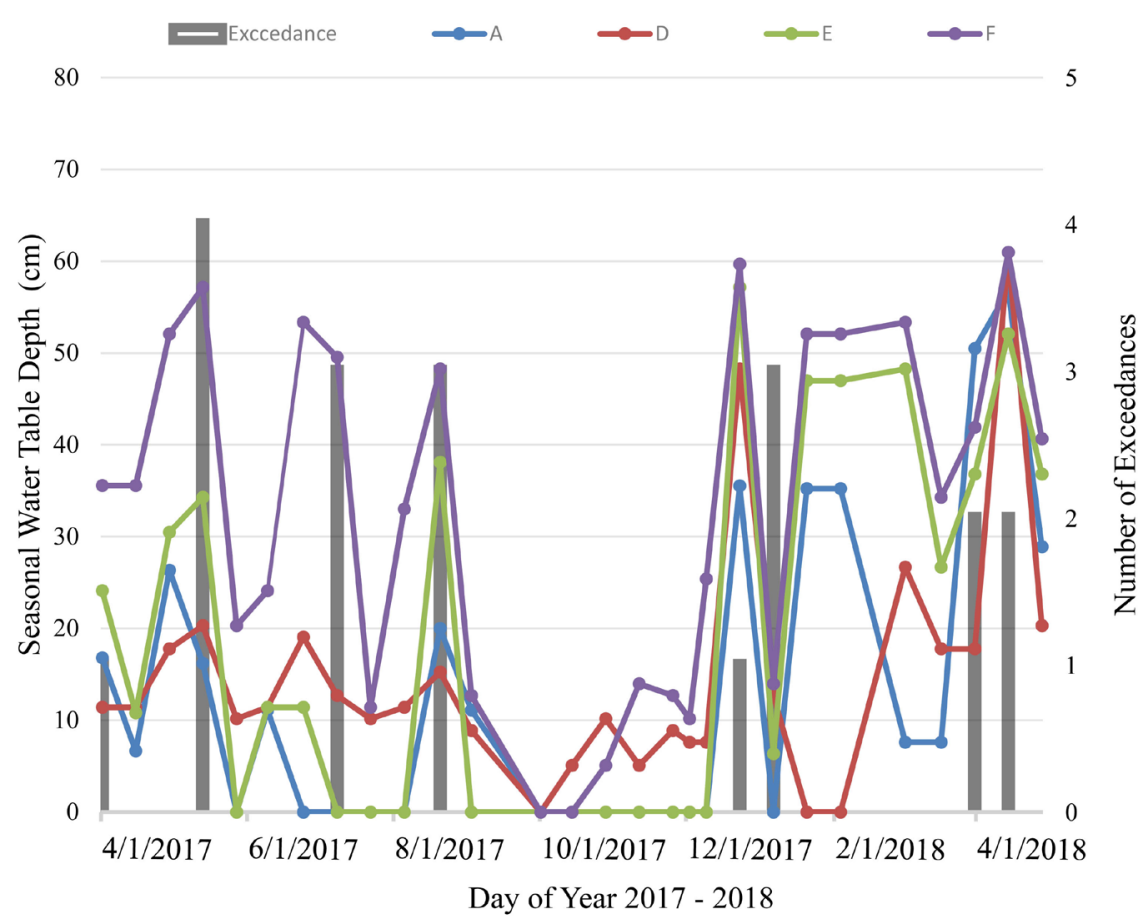

Figure 10. Seasonal water table fluctuations compared to exceedances. The surface is represented on the left $\mathrm{y}$ axis by the $80-\mathrm{cm}$ mark. The bottom of the observation port is represented on the left $y$ axis by the $0-\mathrm{cm}$ mark. The number of exceedances is represented on the right $y$ axis. The exceedances represent any monitored period $>14$ days where any of the trenches in sites A, D, E or F had a ponding depth $>27 \mathrm{~cm}$. Site B and $\mathrm{C}$ are not represented because no seasonal water table was measured, nor exceedance recorded during the study for these two sites.

\subsubsection{Hydraulic Loading}

The accepted flow for a three-bedroom home per the Arkansas Rules and Regulations is $1400 \mathrm{~L} \cdot \mathrm{d}^{-1}$ [2]. The four non-mounded sites had average daily flows $>$ 454 to $<1749 \mathrm{~L} \cdot \mathrm{d}^{-1}$ (Table 3 ). The objective of the study was to load each disposal site at a minimum of two times the loading defined by Tyler [5] for secondary-treated effluent. Flows were recorded and adjustments were made from January through February 2017 to meet the minimum objective. Site A had excess flow due to additional infiltration and inflow of climatic water. Site D measured minimal flows from the home and did not have an exceedance or ponding depth to record in any trench, except for one occurrence on December 23, 2017 when a ponding depth was measured after a 7.6-cm rain the night before. However, the ponded water was no longer evident in the disposal trench three days later. Site $\mathrm{E}$ and $\mathrm{F}$ had expected flows for a three-bedroom home of 697 to $768 \mathrm{~L} \cdot \mathrm{d}^{-1}$. The four non-mounded sites achieved $>2$, but $<3.8$ times the accepted loading rate for secondary-treated effluent (Table 3 ).

\subsubsection{Lateral Movement}

Due to the $2 \%$ to $4 \%$ slope of the disposal areas at all four research sites, sub-surface lateral movement of secondary-treated effluent between trenches was expected and evolved over the study period. From January through February 
Table 3. Summary of average daily flow and loading rates among the six research sites. Flows were recorded at the flow meters entering the disposal site at 14-day intervals throughout the study. Average flows are reported. Flows were also compared to home water meter reading to verify accuracy.

\begin{tabular}{cccccc}
\hline Site & Flow $\left(\mathrm{L} \cdot \mathrm{d}^{-1}\right)$ & Disposal area $\left(\mathrm{m}^{2}\right)$ & Design $\left(\mathrm{L} \cdot \mathrm{m}^{2} \cdot \mathrm{d}^{-1}\right)$ & Actual $\left(\mathrm{L} \cdot \mathrm{m}^{2} \cdot \mathrm{d}^{-1}\right)$ & Multiplier \\
\hline A & 1749 & 37.6 & 12.2 & 46.5 & 3.8 \\
B & 863 & 7.0 & 32.5 & 123.3 & 3.8 \\
C & 458 & 5.6 & 32.5 & 81.5 & 2.5 \\
D & 488 & 9.8 & 12.2 & 49.7 & 2.0 \\
E & 697 & 29.3 & 12.2 & 23.8 & 2.0 \\
F & 772 & 29.3 & 12.2 & 26.3 & 2.2 \\
\hline
\end{tabular}

2017, the ponding depths from line 1 (i.e. the most up-slope line) through line 4 (i.e. the most downslope line) remained relatively uniform with similar ponding depths in each disposal trench in three of the four sites. However, beginning in March 2017 through the remainder of the study, the ponding depths among trenches developed dissimilarities. Line 1 typically had the lowest or non-existent ponding depth and lines 2,3 , and 4 would all show incrementally greater ponding depths the further downslope. The disposal area was receiving secondary-treated effluent through the low-pressure distribution laterals equally over the entire disposal area; however, after the first 30 days, the secondary-treated effluent followed a tortuous path from trench line 1 to the downslope disposal trenches.

Based on all temporal measurements, ponding depths differed $(P<0.03)$ among lines at Sites A, E, and F, but were unaffected by trench line at Site D, where mean ponding depth averaged $0.9 \mathrm{~cm}$ across all four lines throughout the entire study (Table 4). At Site A, mean in-trench ponding depth increased by a factor of 1.8 from lines 1 and 2, which did not differ, to lines 3 and 4, which did not differ. At Sites $\mathrm{E}$ and F, mean ponding depth increased 6- and nearly 2 -fold, respectively, from line 1 to lines 2 and 3, which did not differ. Understanding the lateral, sub-surface flow phenomenon may allow a designer to hydraulically load the upslope-most disposal trench with more secondary-treated effluent and, by the same logic, hydraulically load the more downslope trenches with less secondary-treated effluent and expect effluent renovation from sub-surface, lateral movement of effluent between trenches.

Among the four non-mounded sites, none of the four lines at any site had ponding depths that changed over time throughout the duration of the study, except for line 4 at Site $\mathrm{F}$, which significantly decreased over time ( $P=0.01$; Table 5). These results indicate that, at least within the first 18 months after initial dosing, the secondary-treated effluent was of sufficient quality to minimize biomat formation which is often cited as the reason for absorption field failure when using primary-treated effluent. 
Table 4. Summary of effect of disposal-area trench line on ponding depth over time by site.

\begin{tabular}{cccccc}
\hline \multirow{2}{*}{ Site $^{\mathrm{a}}$} & $P$ & \multicolumn{4}{c}{ Mean Ponding Depth $(\mathrm{cm})$} \\
\cline { 3 - 5 } & & Line 1 & Line 2 & Line 3 & Line 4 \\
\hline A & 0.03 & $5.4 \mathrm{a}^{\mathrm{b}}$ & $8.2 \mathrm{a}$ & $11.5 \mathrm{~b}$ & $13.1 \mathrm{~b}$ \\
B & 0.01 & $0.0 \mathrm{a}$ & $0.1 \mathrm{a}$ & $0.1 \mathrm{a}$ & $0.7 \mathrm{~b}$ \\
C & 0.33 & 0.2 & 0.7 & 1.3 & - \\
D & 0.99 & 0.6 & 0.9 & 0.9 & 1.1 \\
E & 0.01 & $0.9 \mathrm{a}$ & $6.0 \mathrm{~b}$ & $5.1 \mathrm{~b}$ & $0.0 \mathrm{a}$ \\
F & $<0.01$ & $13.9 \mathrm{a}$ & $25.3 \mathrm{~b}$ & $25.9 \mathrm{~b}$ & $12.4 \mathrm{a}$ \\
\hline
\end{tabular}

a'Sites A, D, E, and F were non-mounded sites and had effluent dosed to lines $1-4,1,1-3$, and $1-3$, respectively. Sites B and C were mounded and had effluent dosed to only line $1 .{ }^{b}$ Means within a row with different lower case letters are significantly different at $P<0.05$.

Table 5. Summary of linear regression analyses among all temporal measurements to assess whether ponding depths were increasing, decreasing, or not changing over time. Bolded values were considered significant at the 0.05 level. The arrows in parentheses indicate whether the ponding depth trend was increasing or decreasing.

\begin{tabular}{cccccc}
\hline Site & Line 1 & Line 2 & Line 3 & Line 4 & Observation Well \\
\hline A & 0.09 & 0.24 & 0.94 & 0.78 & $0.04(\uparrow)$ \\
B & - & 0.17 & 0.17 & 0.10 & - \\
C & 0.96 & 0.19 & 0.15 & - & - \\
D & 0.58 & 0.58 & 0.58 & 0.58 & 0.13 \\
E & 0.78 & 0.83 & 0.39 & 0.53 & 0.07 \\
F & 0.20 & 0.14 & 0.15 & $0.01(\downarrow)$ & 0.60 \\
\hline
\end{tabular}

\subsubsection{Wet Spring and Dry Fall Impacts on Disposal Sites}

Shallow seasonal water tables noted in the non-mounded disposal Sites A, D, E and $\mathrm{F}$ showed redoximorphic indicators in the upper $30 \mathrm{~cm}$ of soil. Seasonal water table fluctuations between March and July 2017 directly impacted ponding depths (Figure 6 and Figure 7). Measuring ponding depths in disposal trenches stressed by shallow seasonal water table fluctuations provided insight into how limiting soil profiles, due to a shallow seasonal water table and during stressed conditions, may still provide an acceptable method for disposal and renovation of secondary-treated effluent. During the dry period from August through December 2017, the limited or absence of a seasonal water table provided insight into how limiting soil profiles performed without the influence of seasonal water table fluctuations (Figure 8 and Figure 9). Comparing the average ponding depth of the most hydraulically loaded disposal trench (lowest) during March through July 2017 to the average ponding depth of the same disposal trench from August through December 2017, there was a 38\% reduction in the ponding 
depth during the dry period. Managing the shallow seasonal water table in a limiting soil profile and its impact on a disposal area was not part of this study; however, the observation could be made that, if a soil profile was limiting due to a shallow seasonal water table and the seasonal water table was diverted around the disposal area using an interceptor drain, the efficiency of the disposal area in the disposal area would improve.

\subsubsection{Ponding Depths for Site A vs. Site D}

Sites A and D were located on the same landscape position (backslope), had the same slope (3\%), and similar soil profile characteristics, with the minor exception of the depth to the textural change (Table 1). Site A had a textural change from extremely gravely loam to clay at a depth of $30 \mathrm{~cm}$, while Site D had a textural change from extremely gravely loam to clay at a depth of $40 \mathrm{~cm}$. This small difference resulted in Site A having a measurable ponding depth in one or all of the disposal trenches throughout the study, where Site D did not have measurable ponding in any of the disposal trenches throughout the study, with exception of after a single rain event in December 2017. The secondary-treated effluent being evenly dispersed over the disposal area in small doses throughout the day was able to percolate through the profile at Site D due to the $10-\mathrm{cm}$ zone of extremely gravely loam and move laterally downslope. The secondary-treated effluent at Site A ponded at the textural transition to clay at the $30-\mathrm{cm}$ depth. Based on the data collected, textural changes in the profile should be taken into consideration when contemplating disposal of secondary-treated effluent in a reduced disposal area in profile-limiting soils, which should apply to any disposal site, regardless of using primary or secondary-treated effluent.

\subsubsection{Visual Changes in Vegetation}

Landscape vegetation within the disposal areas and downslope from the disposal areas was notable. Sites A and F were affected downslope the greatest with changes in vegetation and a noticeable plume of nutrient-rich deposition, likely phosphorus and nitrogen-rich solution, as a result of the up-slope disposal area. Sites D and E had no noticeable change within or downslope from the disposal area. Observing the changes in vegetation throughout the study highlighted where the secondary-treated effluent was traveling laterally and downslope. The sites with noticeable changes in vegetation were also the sites that had exceedances. Sites D and E had no noticeable changes in vegetation and fewer exceedances. Vegetation on or downslope from a disposal area can be an indicator of the efficiency or stress experienced in a disposal area.

\subsubsection{Ponding Depths in Line 4 When Line 4 Was Turned off}

During the initial measurement period from September 2016 to February 2017, the number of disposal trenches utilized during the study was adjusted to reflect a loading rate at a minimum of two times the accepted loading rate for secondary-treated effluent. Each disposal site was tied to a homeowners' water usage 
habits and being able to turn off a disposal trench (i.e. allow no effluent to be delivered to a trench) to achieve the focus of the study was necessary. Site A had disposal lines 1 through 4 utilized during the entire study. Sites $\mathrm{E}$ and $\mathrm{F}$ had three of the four disposal lines utilized during the study (i.e. lines 1, 2, and 3). Site D used only one of the four disposal lines during the study (i.e. line 1). Although Sites D, E, and F had at least one disposal line turned off, ponding depths were still recorded for each of the four-disposal lines. Site A always had a measurable ponding depth in the lower disposal trench (Figure 11(a)). Sites E (Figure 11(b)) and F (Figure 12(a)) had measurable ponding depths in line 4. Site D did not have any measurable ponding to record for the duration of the

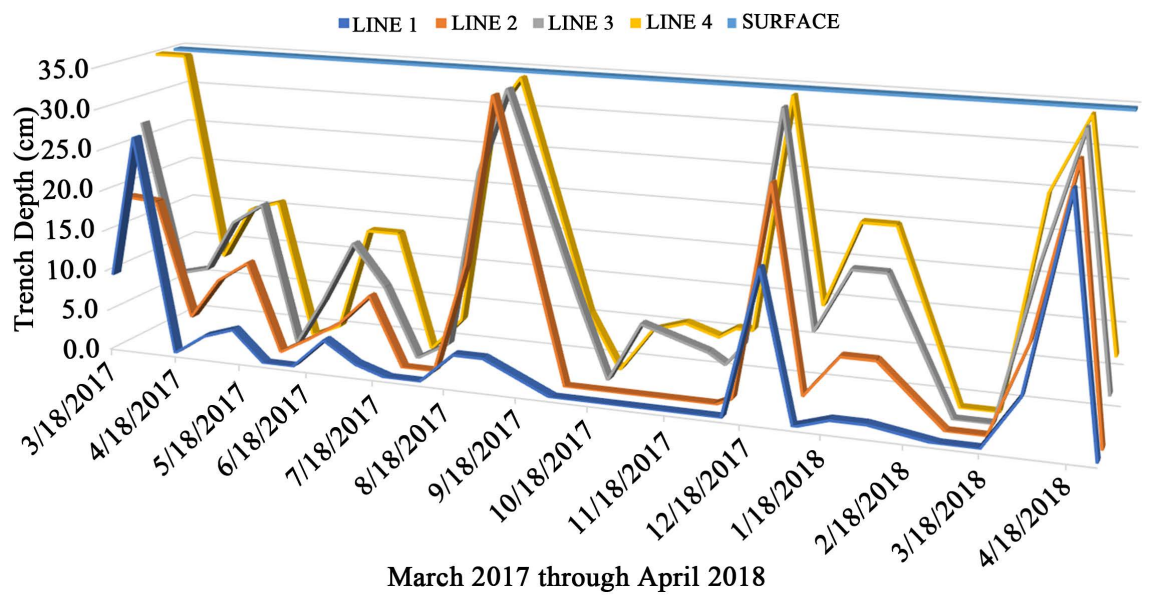

(a)

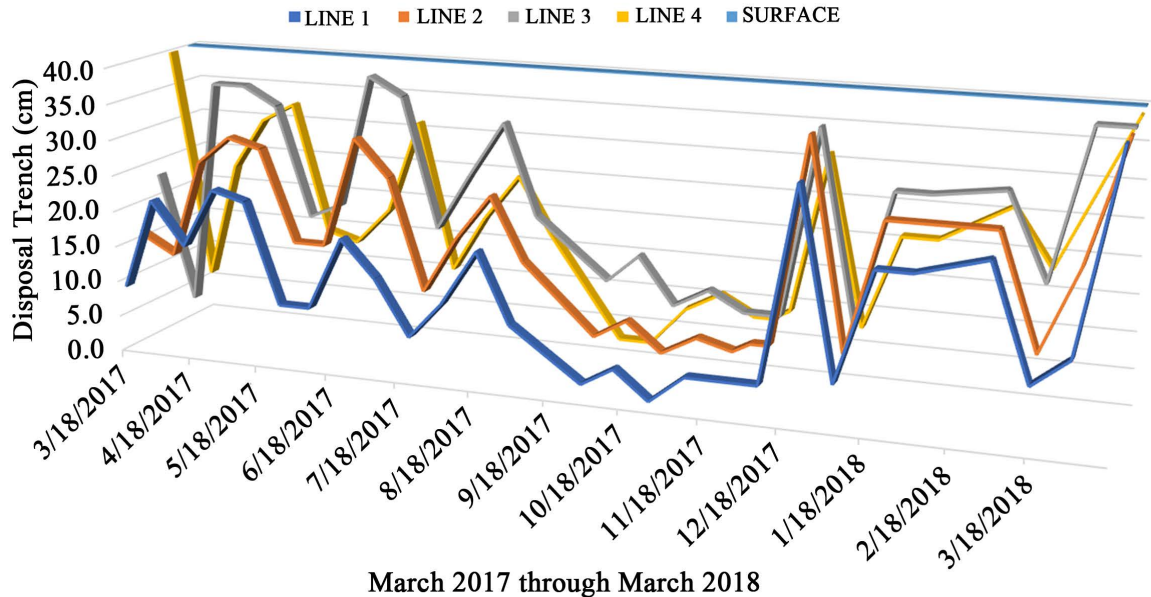

(b)

Figure 11. Lateral movement of secondary-treated effluent at Site A (a) and Site E (b). Observation dates are represented on the $\mathrm{x}$ axis. The $\mathrm{y}$ axis represents the depth of the disposal trench where $35 \mathrm{~cm}$ is the surface for Site A and $40 \mathrm{~cm}$ is the surface for Site E and $0 \mathrm{~cm}$ represents the bottom of the trench. Although the secondary-treated effluent is evenly distributed to the disposal trenches, ponding depths incrementally increased as the water moved laterally downslope. Line 4 at Site E was turned off in March 2017; however, a ponding depth was recorded throughout the study, further highlighting the lateral movement of secondary-treated effluent in the disposal area. 


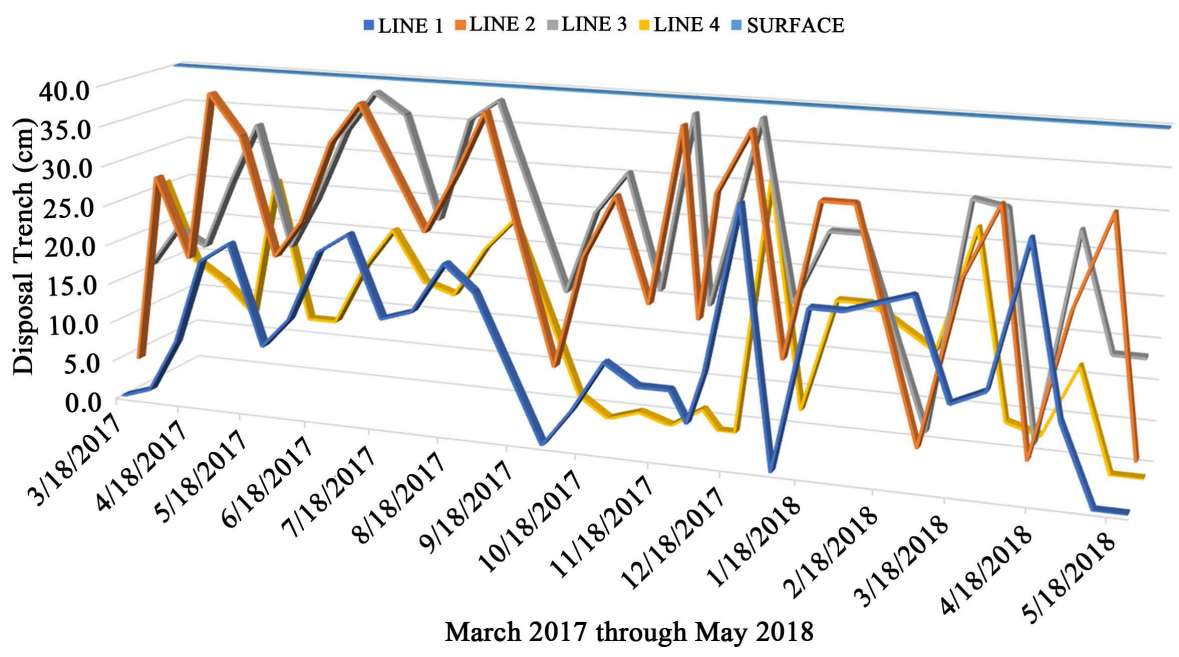

(a)

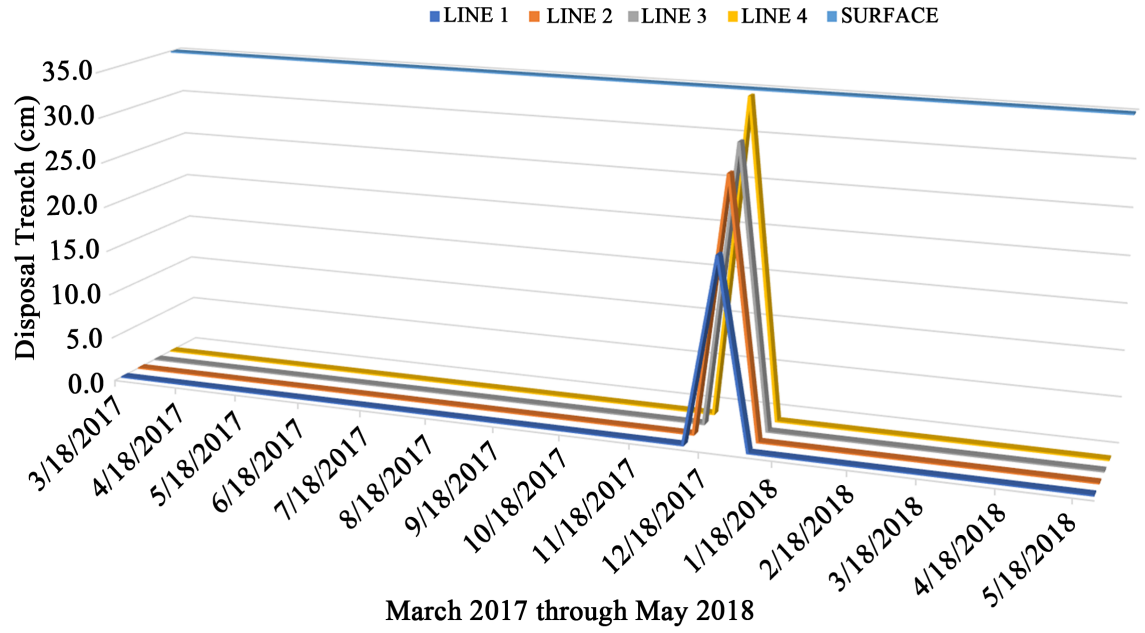

(b)

Figure 12. Lateral movement of secondary-treated effluent at Site F (a) and Site D (b). Observation dates are represented on the $\mathrm{x}$ axis. The $\mathrm{y}$ axis represents the depth of the disposal trench where $40 \mathrm{~cm}$ is the surface at Site F and $35 \mathrm{~cm}$ is the surface at Site D and $0 \mathrm{~cm}$ represent the bottom of the trench. Although the secondary-treated effluent is evenly distributed to the disposal trenches, ponding depths incrementally increased as the water moved laterally downslope. Ponding depths at Site D were only recorded in December 2018 after a heavy rain the night before, while 3 days later, ponding was non-measurable. Lines 2, 3 and 4 at Site D were turned off in March 2017.

study, with exception of after a single rain event in December 2017 (Figure 12(b)). Observing the ponding depths in the lower disposal lines, when secondary-treated effluent was not delivered to the lowest disposal line, clearly demonstrated the sub-surface, lateral movement of the secondary-treated effluent downslope. Based on the data, the concept of sub-surface, lateral flow should be considered in the design criteria when using a reduced disposal area and secondary-treated effluent in profile-limiting soils, as sub-surface, lateral movement of effluent would still provide renovation despite the effluent's minimal vertical flow in the soil profile. 


\subsection{Mounded Sites}

\subsubsection{Seasonal Water Table Impacts on Ponding Depths}

Soil characteristics in the mounded sites showed suitable soils for primary-treated effluent disposal, but with limited disposal area. The A and E horizons, which occupied the top $40 \mathrm{~cm}$, were loam textured with a 10YR 4/3 matrix color and showed no redoximorphic features. The B horizon was a loam in the 40 - to $120-\mathrm{cm}$ depth with a matrix color of $10 \mathrm{YR} 5 / 4$ with depletions of $10 \mathrm{YR}$ $7 / 2$ color and concentrations of $10 \mathrm{YR} 3 / 6$ color noted from in the $55-$ to $120-\mathrm{cm}$ depth interval. The redoximorphic features noted at the $55 \mathrm{~cm}$ depth were well-below the disposal trench depth of $35 \mathrm{~cm}$. Observation well ponding depth measurements recorded at Sites B and C from March 2017 through March 2018 showed no seasonal water table. Based on the data collected, the seasonal water table was not a limiting factor for secondary-treated effluent disposal at Sites B or C.

\subsubsection{Peak Flows}

Each mounded disposal site studied had existing infrastructure in place that included a 946-L dose chamber. The size of the dose chamber was adequate for dosing secondary-treated effluent to an overland-flow point. However, similar to the non-mounded sites, dosing secondary-treated effluent to a reduced disposal area would have benefited from having a larger dose tank. A larger dose tank would have allowed for improved equalization during peak-flow events. However, peak flows throughout the study did not show evidence of an exceedance in ponding depth in either of the mounded Sites B or C.

\subsubsection{Size of Disposal Areas}

The mounded disposal areas that received secondary-treated effluent covered 60 $\mathrm{m}^{2}$. Each of the two sites had four lines, 12-, 15-, 18-, and 21-m long on 1.2-m centers. The depth to redoximorphic features of the soil in the mounded sites translated into a loading rate in the Arkansas Rules and Regulations [2] of 30.5 $\mathrm{L} \cdot \mathrm{m}^{-2} \cdot \mathrm{d}^{-1}$ using a standard trench spacing of $2.4 \mathrm{~m}$, thus the disposal area would have required $145 \mathrm{~m}^{2}$ using primary-treated effluent. Utilizing secondary-treated effluent in a reduced disposal area required $41 \%$ the area required for primary-treated effluent. Similar to the non-mounded sites, the disposal-area reduction is significant when contemplating an alternative method to disposing of secondary-treated effluent other than by overland-flow surface discharging.

\subsubsection{Hydraulic Loading}

The two mounded sites had average daily flows that ranged from $>416$ to $<1703$ $\mathrm{L} \cdot \mathrm{d}^{-1}$ (Table 4), whereas the accepted, estimated flow for a three-bedroom home is $1400 \mathrm{~L} \cdot \mathrm{d}^{-1}[2]$. Neither site B nor C had enough flow to measure an exceedance or ponding depth in any of the disposal lines throughout the entire study. The two mounded sites achieved $>2.5$, but $<3.8$ times the accepted loading rate for secondary-treated effluent (Table 5). 


\subsubsection{Wet Spring and Dry Fall Impacts on Disposal Sites}

In contrast to the non-mounded sites, Sites $\mathrm{B}$ and $\mathrm{C}$ had redoximorphic features below $55 \mathrm{~cm}$. No appreciable ponding was documented at Site B or C throughout the study. Thus, season, either wet or dry, did not affect the performance of the disposal trenches. The disposal trenches at Sites B and C were installed at 36 $\mathrm{cm}$, which was above the depth to redoximorphic features. Installing disposal trenches above a fluctuating, seasonal water table improves the ability of the trench to disperse and renovate the introduced wastewater.

\subsubsection{Visual Changes in Vegetation}

In contrast to the non-mounded sites, changes in landscape vegetation within the mounded disposal areas, or downslope from the mounded disposal areas, were negligible. Sites B and C did not show any changes in vegetation within or downslope of the disposal area, which corresponded with the lack of any ponding-depth exceedances recorded during the study.

\subsubsection{Ponding Depths in Line 4 When Line 4 Was Turned off}

Similar to the non-mounded sites, during the initial measurement period from September 2016 to February 2017, the number of disposal trenches utilized during the study were adjusted to reflect a loading rate at a minimum of two times the accepted loading rate for secondary-treated effluent. Sites B and C used only one of the four disposal lines during the study (i.e. line 1). Though Site B had significantly greater mean ponding in line 4 than in the other three lines, the mean ponding depth was only $0.7 \mathrm{~cm}$ (Table 4). Similarly, ponding depth did not differ among lines at Site $C$ and averaged only $0.7 \mathrm{~cm}$ per line throughout the duration of the study (Table 4). Thus, Sites B and C did not have any appreciable effluent/water ponding for the duration of the study in any of the lower disposal trenches beyond line 1. Consequently, in contrast to the non-mounded sites, lateral movement of secondary-treated was not evident at Sites B or C throughout the study.

Similar to most of the non-mounded sites, ponding depth in the lines at the two mounded sites did not change over time (Table 5). The lack of an increase in ponding depth over time lends credibility to the feasibility of using secondary-treated effluent in a shallow drain field with reduced area.

\section{Implications}

If managed properly, secondary-treated effluent disposed in limiting soils or reduced disposal areas can be considered an alternative for disposal sites with limiting soils that previously were deemed unsuitable. Disposing of wastewater back into the soil profile versus an overland-flow discharge protects the environment by utilizing the soil as the final destination (i.e. hydrologic cycle), reduces the regulatory burden and compliance challenges with surface discharges, and is the responsible way to manage the wastewater.

Throughout the study, the impact from fluctuating seasonal water tables was a 
factor in the efficiency of the disposal areas. Further research is required to study the impact of an interceptor drain installed up-slope from the disposal sites in limiting soils to divert the brief seasonal water table around the disposal area to increase the efficiency and decrease the exceedances in the disposal area. An interceptor drain would pair well with what was learned during the study regarding Site A's and D's ponding depths. Sites A and D both had limiting soils, the same slope, and the same textural properties. However, Site D had the disposal trenches installed just above the textural change from loam to clay loam, where Site A had the trenches installed in the clay loam. Site A had in-trench ponding throughout the study, where Site D had no ponding throughout the study. The implications of installing an interceptor drain and installing the trenches at a depth of 25 versus $35 \mathrm{~cm}$ at Sites A, E, and F to remain above the textural change may have resulted in no to fewer exceedances during the study. In summary, understanding the soil profile and textural characteristics, the slope and surrounding landscape position of the disposal area, and understanding the lateral movement of water through the soil profiles suggests it is conceivable to utilize the soil as final disposal for secondary-treated effluent in soils similar to those studied versus a surface discharge.

\section{Conclusions}

Managing wastewater in rural settings is becoming a challenge as Arkansans' move into areas where conventional wastewater systems are not feasible. When considering an alternative to a conventional on-site wastewater system, there are limited empirical data supporting disposing of secondary-treated effluent in limiting soils other than by overland-flow surface discharge. Results showed that soils that may be unsuitable for a conventional on-site wastewater system may be suitable using secondary-treated effluent with a shallow or a reduced disposal area.

Based on the absence of appreciable secondary-treated effluent ponding at Sites B, C, and D during the study and the minimal exceedances in Site A, E, and $\mathrm{F}$, which was linked directly to fluctuating seasonal water tables, it is reasonable to consider hydraulically loading secondary-treated effluent at a rate Tyler [5] established based on soil textures and structure. Consideration must be given to hydraulically loading secondary-treated effluent in unsuitable soils or suitable soils with a reduced disposal area.

\section{Acknowledgements}

The authors gratefully acknowledge the willingness of the various landowners who cooperated by allowing this research to be conducted on their private property.

\section{Conflicts of Interest}

The authors declare no conflicts of interest regarding the publication of this paper. 


\section{References}

[1] Miller, W. (2017) Rural Profile of Arkansas 2017. https://www.uaex.edu/publications/pdf/MP541.pdf

[2] Arkansas State Board of Health (ASBH) (2014) Act 402 of 1977: Rules and Regulations.

https://www.healthy.arkansas.gov/images/uploads/rules/OnsiteWastewaterSystems. pdf

[3] Office of Water, Office of Research and Development (OWRD), United States Environmental Protection Agency (USEPA) (2002) USEPA Onsite Wastewater Treatment Systems Manual.

https://www.epa.gov/sites/production/files/2015-06/documents/2004_07_07_septics septic_2002_osdm_all.pdf

[4] Arkansas State Board of Health (ASBH) (2010) Act 402 of 1977: Rules and Regulations Pertaining to Drip Dispersal Systems.

https://www.healthy.arkansas.gov/images/uploads/rules/DripDisposal1.pdf

[5] Tyler, E.J. (2001) Hydraulic Wastewater Loading Rates to Soil. In: On-Site Wastewater Treatment, American Society of Agricultural and Biological Engineers, St. Joseph, 80 .

[6] United States Department of Agriculture (USDA), Soil Conservation Service (SCS) (1981) Land Resource Areas of the United States, Handbook 296. http://soilphysics.okstate.edu/S257/south/mlra/119.htm

[7] McNab, W. and Avers, P. (1994) Ecological Subregions of the United States. https://www.fs.fed.us/land/pubs/ecoregions/ch23.html\#toc\%22

[8] Google Earth (2018) Rushing Road, Little Rock, Arkansas. https://www.google.com/earth

[9] Arkansas Department of Environmental Quality (ADEQ) (2014) Arkansas Water Pollution Control Act (Ark. Code Ann. \$ 8-4-101 et seq.), and the Clean Water Act (33 U.S.C. $\$ 1251$ et seq.). Authorization to Discharge under the National Pollutant Discharge Elimination System and the Arkansas Water and Air Pollution Control Act, Little Rock, Arkansas.

https://www.adeq.state.ar.us/water/permits/npdes/nonstormwater/pdfs/arg550000/ 2014_final_permit.pdf

[10] Gee, G.W. and Or, D. (2002) Particle Size Analysis. In: Dane, J.H. and Topp, G.C., Eds., Methods of Soil Analysis Part 4: Physical Methods, Soil Science Society of America, Madison, 255-293.

[11] Farm Logs (2018) Farm Logs. https://farmlogs.com/about

[12] Farm Logs (2018) How the Rainfall Feature Works. https://farmlogs.com/support/\#understanding-the-features-how-the-rainfall-feature -works

[13] Lowe, K.S. and Siegrist, R.L. (2008) Controlled Field Experiment for Performance Evaluation of Septic Tank Effluent Treatment during Soil Infiltration. Journal of Environment Engineering, 134, 93-101. https://doi.org/10.1061/(ASCE)0733-9372(2008)134:2(93)

[14] Lowe, K.S., Siegrist, R.L. and Tackett, K.N. (2006) Hydraulic Loading Rate and Infiltrative Surface Architecture Effects on Septic Tank Effluent Treatment during Soil Infiltration. National Onsite Wastewater Recycling Association Technical Education Conference and Exposition Proceedings, Denver, August 28-31.

[15] Gibbons, A., Brye, K.R., Dunn, S., Gbur, E.E., Sharpley, A.N. and Zhang, W. (2015) 
Increased Effluent Dosage Effects on On-Site Wastewater Treatment Systems of Differing Architecture Type. Journal of Environmental Protection, 6, 651-670. https://doi.org/10.4236/jep.2015.66059

[16] Prater, N.J.M., Brye, K.R., Dunn, S., Soerens, T.S., Sharpley, A.N., Mason, E.R. and Gbur, E.E. (2013) Effluent Storage and Biomat Occurrence among Septic System Disposal Field Architectures in a Typic Fragiudult. Journal of Environmental Quality, 42, 1213-1225. https://doi.org/10.2134/jeq2012.0373 